July $1997 \bullet$ NREL/SR-540-22626 • UC Category: 1504

\title{
Emissions and Performance Evaluation of a Dedicated Compressed Natural Gas Saturn
}

\author{
Jeffrey W. Hodgson and John D. Taylor \\ The University of Tennessee \\ Knoxville, Tennessee
}

NREL Technical Monitor: Peg Whalen

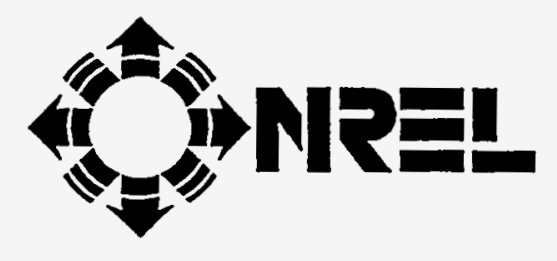

National Renewable Energy Laboratory

1617 Cole Boulevard

Golden, Colorado 80401-3393

A national laboratory of the

U.S. Department of Energy

Managed by the Midwest Research Institute

For the U.S. Department of Energy

Under Contract NO. DE-AC36-83CH10093

Prepared under Subcontract Number XCF-5-14050-03

July 1997 


\section{NOTICE}

This report was prepared as an account of work sponsored by an agency of the United States government. Neither the United States government nor any agency thereof, nor any of their employees, makes any warranty, express or implied, or assumes any legal liability or responsibility for the accuracy, completeness, or usefulness of any information, apparatus, product, or process disclosed, or represents that its use would not infringe privately owned rights. Reference herein to any specific commercial product, process, or service by trade name, trademark, manufacturer, or otherwise does not necessariiy consitiute or imply its endorsement, recommendation, or favoring by the United States govemment or any agency thereof. The views and opinions of authors expressed herein do not necessarily state or reflect those of the United States government or any agency thereof.

Available to DOE and DOE contractors from:

Office of Scientific and Technical Information (OSTI)

P.O. Box 62

Oak Ridge, TN 37831

Prices available by calling (423) 576-8401

Available to the public from:

National Technical Information Service (NTIS)

U.S. Department of Commerce

5285 Port Royal Road

Springfield, VA 22161

(703) $487-4650$ 


\section{DISCLAIMER}

Portions of this document may be illegible in electronic image products. Images are produced from the best available original document. 


\section{Preface}

\section{Background}

The use of compressed natural gas (CNG) as a transportation fuel has been identified as one strategy that can help ameliorate some problems, which include a growing dependence on imported oil (and all its ramifications) and the persistent contributions that mobile sources make to urban air pollution, associated with the use of conventional petroleum fuels.

The attributes and limitations of CNG as a fuel for spark-ignition engines have been presented by others (Weaver 1989). The attributes are associated with its high octane rating, low cost relative to other alternative fuels, its availability, the absence of running and diumal evaporative emissions, and its demonstrated potential for producing extremely low exhaust emissions-particularly if the volatile organic compounds (VOCs) emitted are expressed in terms of reactivity adjusted non-methane organic gases (RANMOG). The limitations associated with the use of $\mathrm{CNG}$ include its limited refueling infrastructure, the cost of refueling facilities, the cost of on-board fuel storage tanks, and its relatively low energy density.

In order for the higher (relative to the gasoline-fueled baseline vehicle) initial cost of a CNGfueled vehicle to be recouped by the lower fuel price, CNG is most attractive in high fuel use applications. If the initial cost can be reduced, however, the economic viability of the fuel can be extended to lower fuel use applications. The use of CNG in small vehicles is especially challenging in that the incremental cost associated with the CNG system typically represents a higher fraction of the total vehicle cost than would be the case with larger, more expensive vehicles. In addition, because small vehicles are typically very fuel efficient, fuel costs may not represent an important factor for the vehicle owner. Small vehicles also present greater system packaging problems because the space available for the fuel tanks is more limited than for larger vehicles.

Because one impediment to CNG use is the cost associated with producing a CNG-powered vehicle, a study was initiated at the University of Tennessee under sponsorship by the Saturn Corporation to determine how a CNG vehicle (specifically, a 1991 Saturn SL1) could be engineered so it could be produced with a minimal impact on the production of the base vehicle. The objectives of the design were:

- The vehicle should have a highway range of at least $330 \mathrm{~km}$ (200 miles)

- The utility of the vehicle should be maintained as much as possible

- The vehicle should meet anticipated emissions regulations

- The vehicle conversion should have minimal impact on the base vehicle production and should not involve major modifications to the base vehicle

- The conversion must meet the relevant recognized safety standards (National Fire Protection Association 1992). 
The study is complete and has been reported in the literature (Hodgson 1995). The design chosen was a dedicated CNG configuration with port fuel injection. The vehicle had a single CNG tank in the trunk and used a different piston configuration to raise the stock compression ratio from 9 to 11 . The highway range (based on actual highway fuel consumption) was $400 \mathrm{~km}$ ( 250 miles), and the emissions were just within the California ULEV limits with a relatively new catalyst.

While the study was being performed, Honda (Matsuura 1994) and Daewoo (Kim 1994) revealed their small CNG vehicle designs, which were remarkably similar to the University of Tennessee design. All three were dedicated CNG vehicles, and shared the following features:

- A single CNG tank in the trunk between the wheel wells

- Multiport gaseous fuel injection

- Increased compression ratio

- A special natural gas catalyst.

Johns Hopkins University (Wozniak 1996) and Canadian researchers (Brown 1996) have also presented designs for small vehicles that operate on CNG. The Johns Hopkins design features a special trailing arm rear suspension that allows a noncylindrical CNG tank to be placed under the vehicle. The Canadian design is for a special delivery service vehicle with tanks beneath the passenger compartment floor.

\section{The Present Study}

The present study was undertaken to further investigate the emissions reduction potential of the Saturn CNG vehicle. In the previous study (Hodgson 1995) the role of exhaust gas recirculation was not thoroughly investigated. Those involved in the study agreed that the $\mathrm{NO}_{\mathrm{x}}$ levels could be brought down well below ULEV levels without increasing either the non-methane organic gases or the $\mathrm{CO}$ levels.

\section{Acknowledgments}

Several people and organizations contributed to this study. We would like to express our appreciation to the National Renewable Energy Laboratory for supporting the study and to our subcontract technical monitors, Chris Colucci and Peg Whalen, who provided encouragement and advice. The work could not have been completed without the cooperation of colleagues at Saturn Corporation and consultation from United Emission Catalysts. The assistance of Dr. Kenneth Knapp at the Environmental Protection Agency in Research Triangle Park, North Carolina, is gratefully acknowledged. We also want to thank Paul Hensley, who allowed us to use his gasoline-fueled 1991 Saturn SL1 for the acceleration tests. 


\section{Summary}

We have completed a study in which a 1991 Saturn SL1, which had been converted to dedicated compressed natural gas (CNG) service, was tuned for very low emissions. Our study focused on examining the roles played by stoichiometry, spark timing, and exhaust gas recirculation, and we found that each parameter had important effects on one or more of the exhaust gas components of interest. The vehicle was equipped with a close-coupled production gasoline-fueled Saturn catalyst and a main under-floor catalyst formulated specifically for natural gas. The results show that with fresh catalysts the vehicle achieved emissions levels well below the California ULEV values. The final emissions values were:

$\begin{array}{lll}\text { CO: } & 0.64 \mathrm{~g} / \mathrm{mi} & (1.70) \\ \text { NO }_{\mathrm{x}}: & 0.04 \text { “ } & (0.20) \\ \text { RANMOG*: } & 0.009 \text { “ } & (1.70)\end{array}$

(*RANMOG is the reactivity-adjusted non-methane organic gases; the numbers in parentheses are the ULEV targets)

Acceleration tests showed that the vehicle has reduced acceleration capability at the same speed and in the same gear as its gasoline-fueled counterpart.

We conclude that a dedicated CNG compact vehicle can be produced with relatively minor changes to the base vehicle and that such a vehicle can have acceptable range and driveability while promising extremely low emissions. 


\section{Contents}

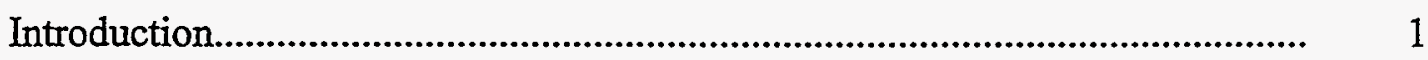

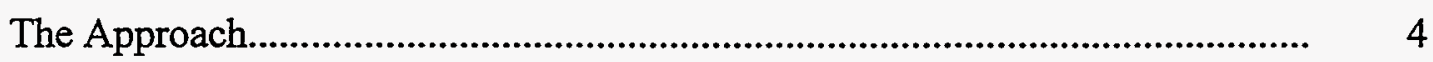

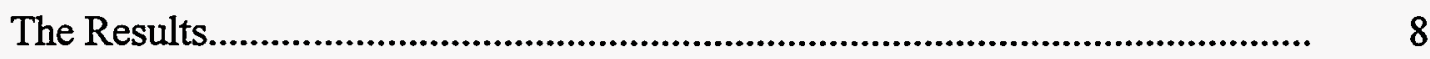

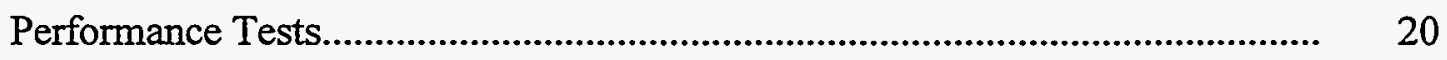

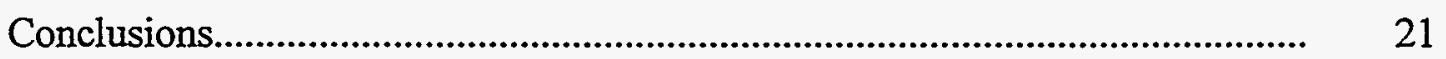

Bibliography..................................................................................... 22

Appendix A: Composition of CNG in Knoxville................................................. 24

Appendix B: Detailed Emission Test Reports....................................................... 25

Appendix C: Calculation of Reactivity-Adjusted NMOG Emissions................... 40

Appendix D: Acceleration Test Results..............................................................

\section{List of Figures}

Figure 1. Typical spark-ignition engine emissions as a function of fuel-air equivalence ratio

Figure 2. Conversion efficiency of a typical threeway catalyst as a function of fuel air ratio.

Figure 3. Engine out emissions versus exhaust gas recirculation rate............... 10

Figure 4. Engine out emissions $\left(\mathrm{NO}_{x}\right)$ as a function of spark advance and GPO output (EGR)

Figure 5. Spark advance as a function of engine speed and intake manifold pressure.

Figure 6. Specified vehicle speed versus time trace for FTP urban driving cycle

Figure 7a Real-time emissions (Bag 1). 
Figure 7b. Real-time emissions (Bag 2)........................................................

Figure 7c. Real-time emissions (Bag 3).......................................................... 15

Figure 8. Vehicle acceleration comparison - CNG vs. Gasoline........................ 21

Figure D1 Vehicle speed as a function of time (1st gear).............................. 42

Figure D2. Vehicle speed as a function of time (2nd gear)........................... 42

Figure D3. Vehicle speed as a function of time (3rd gear)............................. 43

Figure D4. Vehicle speed as a function of time (4th gear)............................... 43

\section{List of Tables}

Table 1. First series of emission tests Bag 3 results only.................................. 12

Table 2. Initial catalyst efficiency values.......................................................... 12

Table 3. Second series of emission tests-Bag 3 results only........................... 13

Table 4. Emission results compared to ULEV values........................................ 13

Table 5. Major hydrocarbon species present (Test 13)......................................... 17

Table 6. Breakdown of aldehydes (Test 13)...................................................... 17

Table 7. Exhaust toxics (Test 13) ...................................................................... 18

Table 8 Ozone-Forming Potential of Exhaust Emissions................................... 18

Table 9. Comparison of RFG and CNG vehicle emissions................................ 19

Table A1. Composition of natural gas in Knoxville.............................................. 24 


\section{Introduction}

Natural gas as a fuel for spark-ignition engines offers the potential for extremely low emissions. The evaporative emissions (running and diumal) are essentially eliminated and the exhaust emissions can be extremely low. Unfortunately, first-generation compressed natural gas (CNG) conversion kits (gas mixers without feedback control) do not always achieve low exhaust emissions (Matthews 1996). To realize the low emissions potential of natural gas, electronic engine fuel metering systems, and even catalysts formulated specifically for natural gas, are required.

The primary emissions problem associated with natural gas is that the volatile organic compounds (VOCs) in the exhaust are primarily unburned methane, a relatively inert hydrocarbon (HC). This makes it relatively innocuous as far as tropospheric ozone production is concerned, but also makes it difficult to oxidize in the exhaust system. Some current and future VOC emissions regulations specify non-methane organic gas (NMOG) levels, and the total hydrocarbon (THC) levels do not dictate whether the vehicle is in regulatory compliance.

Because CNG is introduced into the engine as a gas, cold starting the engine does not require overfueling (as in the case of liquid-fueled engines), and the emissions produced while the catalyst(s) are warming up are lower than they would be if overfueling was required. Natural gas combustion in engines produces emissions that respond qualitatively the same as gasoline to the various engine operating parameters. Each component of interest is discussed briefly here.

\section{Carbon Monoxide}

Carbon monoxide is almost exclusively determined by the stoichiometry under which combustion occurs. Second-order effects are associated with dissociation and frozen equilibrium effects during the expansion process and with increased exhaust temperatures associated with retarded spark timing, but the variable of primary importance is the local airfuel ratio. The use of exhaust gas oxygen (EGO) sensors to control overall engine stoichiometry is almost universal, but individual cylinders can still run fuel rich due to cylinder-to-cylinder variations in air flow, fuel flow, or exhaust gas recirculation (EGR) flows. CO can also result when poor fuel mixing within a cylinder results in rich pockets during combustion. As shown in Figure 1, $\mathrm{CO}$ production is associated with fuel-rich combustion, and control of this component is tied to control of the engine stoichiometry coupled with catalytic exhaust treatment.

\section{Oxides of Nitrogen}

At the high temperatures generated in the combustion chambers of spark-ignition engines, some of the nitrogen present can be partially oxidized to form nitrogen oxides, primarily nitric oxide (although others are also generated). The principal engine operating parameters that influence the formation of oxides of nitrogen $\left(\mathrm{NO}_{\mathrm{x}}\right)$ are stoichiometry (see Figure 1) and 
other parameters that affect the peak combustion temperature. Specifically, spark timing and exhaust gas recirculation have significant effects on the levels of $\mathrm{NO}_{\mathrm{x}}$ produced. Thus, control of $\mathrm{NO}_{\mathrm{x}}$ emissions primarily involves careful control of stoichiometry, spark timing, and EGR coupled with catalytic exhaust gas treatment.

\section{Volatile Organic Compounds}

Exhaust emissions of VOCs result from incomplete combustion within the engine cylinder. Any mechanical problem that allows unburned fuel to escape into the exhaust system (leaky exhaust valves, cylinder misfire) will create high levels of VOCs in the exhaust stream, but other mechanisms are also at work (Cheng 1993). In addition to wall quenching of the flames, absorption and desorption of fuel in the lubricant layer on the cylinder wall, and flame quenching in crevices have been identified as important sources of VOCs. Control of VOCs has been focused on stoichiometry control (see Figure 1), combustion chamber and piston design to reduce crevice volumes, steps to reduce peak pressures so less unburned fuel is forced into crevice volumes during the combustion process, and catalytic exhaust treatment. Retarded spark timing can also reduce VOC levels by reducing peak pressures and by raising the exhaust temperature (which encourages exhaust port oxidation of unburned fuel).

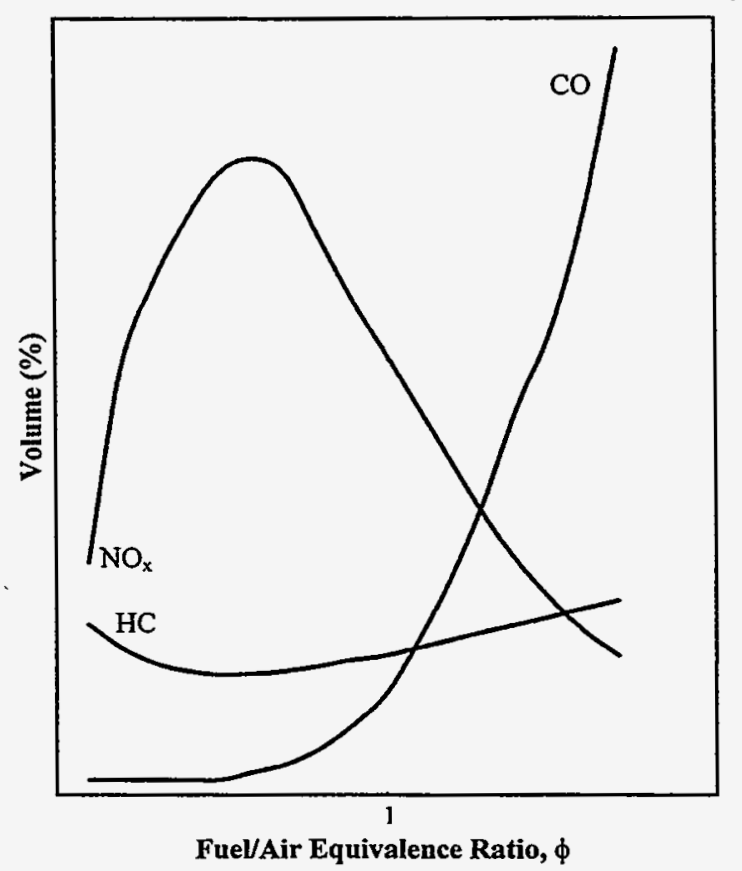

Figure 1. Typical spark-ignition engine emissions as a function of fuel-air equivalence ratio (Stone 1994)

\section{The Three-Way Catalyst}

Catalytic treatment of the exhaust calls for simultaneously oxidizing CO and VOCs while chemically reducing $\mathrm{NO}_{x}$, so early efforts involved dual-bed catalysts that had a reducing section followed by an oxidizing section (sometimes with air provided between the two 
sections). The development of the three-way catalyst, however, simplified this by exposing the gases to a catalyst that essentially allowed the $\mathrm{CO}$ and VOCs to reduce the $\mathrm{NO}_{\mathrm{x}}$. The washcoat materials typically involve palladium and rhodium; platinum is also used in some cases. In order for the three-way catalyst to operate effectively, however, the stoichiometry has to be held in a very narrow window close to an equivalence ratio of unity (see Figure 2). This is currently done by using EGO feedback and electronic fuel metering.

\section{Interaction of Controls}

Figure 1 shows that steps taken to reduce $\mathrm{CO}$ and VOCs (running at fuel lean conditions) can maximize $\mathrm{NO}_{x}$ production. Likewise, running rich to reduce $\mathrm{NO}_{x}$ will increase $\mathrm{CO}$. Other control strategies may also involve trade-offs. For example, retarded spark timing has a beneficial effect on all three components of interest, but has an adverse effect on engine efficiency. Likewise, EGR reduces $\mathrm{NO}_{\mathrm{x}}$ very effectively, but if too much EGR is used, poor combustion stability can adversely affect driveability and VOC emissions.

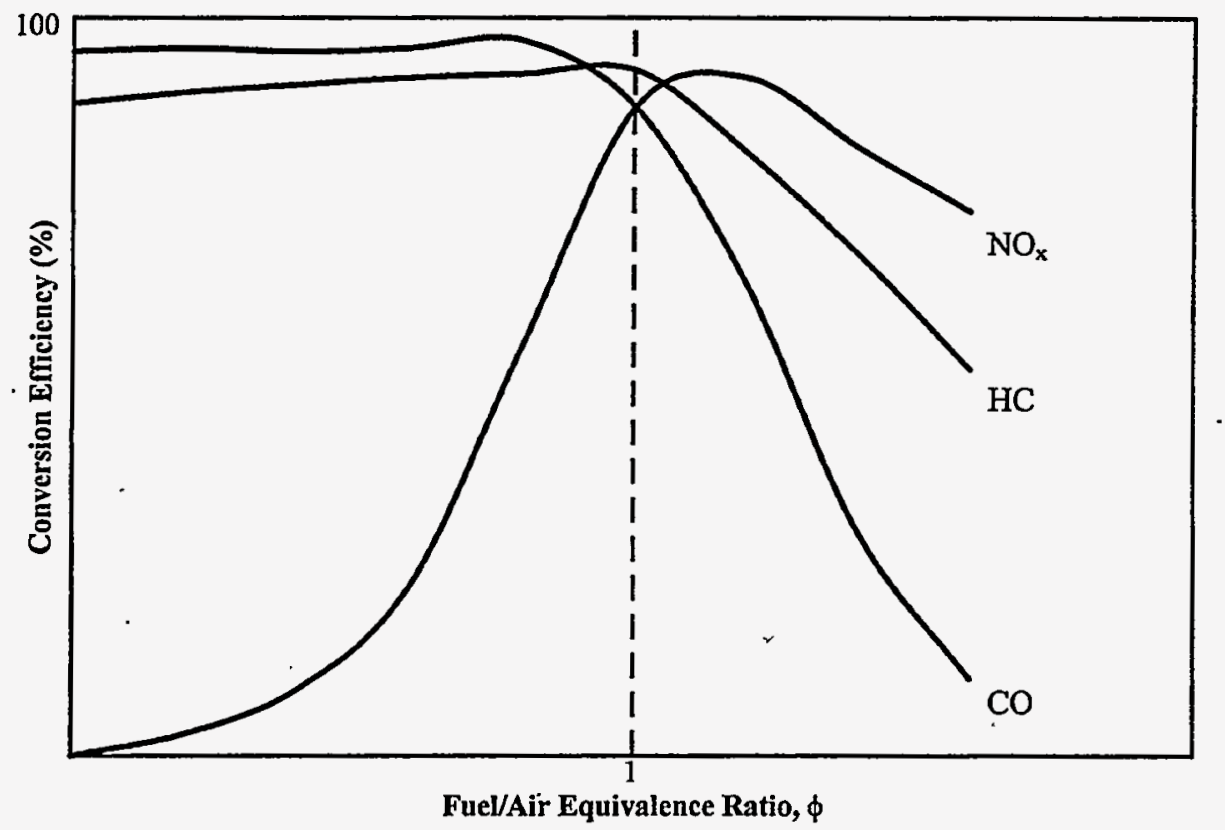

Figure 2. Conversion efficiency of a typical three-way catalyst as a function of fuel-air ratio (Stone 1994)

\section{Purpose of the Current Study}

In the earlier study (Hodgson 1995), reducing emissions was not the primary focus; however, very low emissions levels were achieved. In the present study we focused on reducing the emissions further, with special emphasis on examining EGR calibration as a mechanism for realizing these reductions. We conducted tests to evaluate the effects of EGR, mixture stoichiometry, and spark timing on emissions and driveability. After calibrating the vehicle, we conducted additional FTP emissions testing and some acceleration testing to document the performance of the final configuration. 


\section{The Approach}

\section{Introduction}

To reduce the emissions from the Saturn, we conducted initial testing to determine preliminary engine and operating settings before we conducted expensive and time-consuming Federal Test Procedure (FTP) testing. The fuel used in all the testing was natural gas supplied by the Knoxville Utility Board at its natural gas vehicle refueling facility in Knoxville, Tennessee. The gas has a high (96\%) methane content: An analysis of the gas is included in Appendix A.

\section{The Vehicle}

The test vehicle is a 1991 Saturn SL1-a four-door sedan equipped with a 1.9-L displacement single overhead cam engine, a five-speed manual transmission, and air conditioning. To convert the vehicle to dedicated $\mathrm{CNG}$ operation we:

- Replaced the throttle body gasoline injection system with port fuel injection using Bosch gaseous fuel injectors and a Saturn pre-production port fuel injection intake manifold

- Removed the gasoline fuel system (tank, fuel pump, fuel lines) and the evaporative emission control system components

- Installed a single aluminum e-glass wrapped storage tank in the trunk and the other fuel system components (regulator, shut-off valves, pressure gauges)

- Added an aftermarket engine control system to control fuel metering, ignition timing, and EGR

- Replaced the stock pistons with high-compression pistons to yield a compression ratio of $11: 1$

- Replaced the 1991 model EGR valve with a pre-production electronically controlled (pulse width modulated) EGR valve.

More details can be found in an earlier report (Hodgson 1995), which deals with converting and evaluating the vehicle.

\section{Initial Testing}

The initial testing was conducted at the University of Tennessee and involved steady-state chassis dynamometer testing to gain insight about the effects of stoichiometry, spark timing, and EGR rates on engine-out emissions. 


\section{Equipment}

To perform the initial testing we used the following tools and instruments.

\section{Engine Control System}

The Saturn Corporation considers its engine control system to be proprietary, so we used an aftermarket engine control system from Electromotive, Inc., to conduct our studies. This system uses the speed-density approach for engine control in which the air flow to the engine is inferred from measurements of the intake manifold pressure and temperature, the engine speed, and the engine's volumetric efficiency. It incorporates EGO feedback and has an auxiliary output port (the general purpose output or GPO port), which delivers a pulse-width modulated signal that can be used to control an EGR valve. The controller uses standard General Motors (GM) sensors for input and controls ignition timing, fuel flow, idle speed, and EGR. All these outputs are user specified, and input to the controller is accomplished via a personal computer interface. Once the desired parameters are established, the user loads the settings into the controller's EEPROM and the personal computer interface is removed. Changes can be made while the engine is running if the computer is connected to the engine controller.

\section{Chassis Dynamometer}

Rather than remove the engine from the vehicle for dynamometer testing, we decided to use the University of Tennessee's chassis dynamometer to load the engine during calibrations. The chassis dynamometer, a Sun Electric Corporation Roadamatic, uses an eddy current absorber and can be programmed to maintain a constant vehicle speed or to simulate road loads. It uses 24-in. diameter rolls and can, for brief periods, absorb more than $150 \mathrm{~kW}$ from the vehicle's drive wheels. The eddy current brake is air cooled and cannot maintain this high power absorption without overheating. The road loads are established by dialing in the vehicle mass, air resistance coefficient (drag coefficient times frontal area), and grade to be simulated. The dynamometer control system supplies the eddy current brake with the excitation required to develop a resistive torque, which is in the form of a second-order speed polynomial (i.e., $a+b \mathrm{~N}^{2}$ ) to simulate the grade and the aerodynamic drag and an inertia term that is proportional to the time rate of change of the roller speed (to simulate vehicle mass on acceleration). The rolls have an inertia equivalent to a $1,400-1 b$ vehicle.

In this study we also used a driver aid that enabled the vehicle to be "driven" over the FTP driving cycle. This aid essentially allows the driver to follow a predetermined speed-time trace that is displayed on a computer monitor. The driving cycle is loaded from files containing the desired cycle profile. 


\section{Emission Tester}

Although the University of Tennessee has access to more sophisticated exhaust gas analyzers, we conducted the initial testing with a Micro Processor Systems, Inc. PGA 9000 four gas $\left(\mathrm{CO}, \mathrm{NO}_{x}\right.$, unburned $\mathrm{HCs}$, and $\mathrm{CO}_{2}$ ) infrared analyzer. This analyzer was zeroed and spanned before each use, but because only the relative values of the component concentrations were of interest as engine operating parameters changed, there was no need to conduct detailed calibrations.

\section{Test Plan}

For the initial testing we conducted steady-state tests to determine preliminary air-fuel ratios to be used and the effects of EGR rates and spark timing on emissions. The approach is as follows:

\section{Stoichiometry}

In the previous study (Hodgson 1995) an earlier version of the same engine controller was used. In that study the desired stoichiometric air-fuel ratio was determined by operating the vehicle on a chassis dynamometer to simulate a steady level road speed condition of $50 \mathrm{mph}$. Under these conditions, the EGO sensor switch point voltage was systematically changed and the engine-out $\mathrm{CO}$ values were measured. Typically under such conditions a straight line can be drawn through the data on the lean side of stoichiometric and another straight line through the data on the rich side of stoichiometric when the results are plotted on CO versus EGO switch point voltage coordinates. The switch point voltage for stoichiometric combustion is taken to be that value at which the two straight lines intersect. In essence, this procedure calibrates the EGO sensor. The initial value obtained for the stoichiometric switch point EGO voltage was then refined by examining the results from several FTP tests.

The controller used in the current study does not indicate EGO voltage directly, but is calibrated to indicate an air-fuel ratio (which is based on the EGO voltage). The manufacturer anticipated that the controller would be used with gasoline-fueled engines, so the indicated air-fuel ratios correspond to the EGO voltage that would be generated with gasoline. Thus, an indicated air-fuel ratio of 14.7 is really stoichiometric for any $\mathrm{HC}$ fuel, even though for natural gas the stoichiometric air-fuel ratio is close to 17 .

Rather than repeat the same tests with the second-generation controller, we loaded the same controller parameters into the controller that were used in the earlier version of the controller and determined that the indicated air-fuel ratio was about 14.6 (corresponding to a fuel-air equivalence ratio of about 1.01). We conducted no direct measurements of fuel and air flow to verify this because the indicated air-fuel ratio is simply a controller parameter that indicates the EGO voltage. 


\section{EGR Rates}

The EGR rate was controlled by a pre-production exhaust gas recirculation valve. The position of the pintle in this valve is indicated by an integral potentiometer and determined by the duty cycle provided by the pulse width modulated signal to the valve. The Electromotive controller has an auxiliary port (the GPO port) that can provide such a signal, so it was used to drive the EGR valve. Tests were conducted at several engine operating points to determine the tolerance of the engine to EGR and the effects of the EGR on engine emissions. The use of the duty cycle (the GPO output signal duty cycle) was taken to be the indicator of EGR rate because this is how one would adjust the EGR rate. A secondary reason is that to determine the actual EGR rate we would have to measure and compare the $\mathrm{CO}_{2}$ concentrations in the exhaust and in the intake manifold. This would have been difficult and time-consuming, so we chose the GPO duty cycle as a secondary indicator.

Our objective was to reduce the engine-out $\mathrm{NO}_{\mathrm{x}}$ emissions to the lowest possible value without adversely affecting driveability, so we were interested in determining the maximum amount of EGR the engine could tolerate without incurring problems with engine combustion stability. To accomplish this we operated the engine over a range of speeds and manifold pressures while varying the EGR valve duty cycle and measuring the engine-out $\mathrm{NO}_{\mathrm{x}}$ and $\mathrm{HC}$ concentrations.

\section{Spark Timing}

Spark timing was determined by observing the chassis dynamometer torque for a fixed manifold pressure (throttle position) at a given engine speed while the spark timing was varied. The spark timing was varied by inputting the desired change into the controller while the vehicle operated on the dynamometer. The range of spark timings investigated at each speed was such that the spark timing for best torque was bracketed by spark advances $5^{\circ}$ above and $5^{\circ}$ below that value.

\section{FTP Emission Tests}

The University of Tennessee has no facilities for conducting emission tests in accordance with EPA requirements (Code of Federal Regulations [CFR]), so the vehicle was transported to Research Triangle Park, North Carolina, for testing. There the EPA maintains a state-of-theart emission testing facility that can conduct standard FTP tests, and can speciate the exhaust components and measure exhaust aldehydes. The test plan was to conduct an initial FTP emission test, review the results, make necessary adjustments, and then conduct another FTP test. To evaluate the effects of changes made, "hot 505" runs (discussed later) were used. 


\section{The Results}

\section{Initial Testing}

\section{Initial Air-fuel Ratio Settings}

Once the air-fuel ratio value was established for stoichiometric combustion, the value was entered into the desired air-fuel ratio look-up table in the controller. Once the controller went into "closed loop" operation, it would try to maintain this ratio. The initial testing gave a starting point (an indicated $\mathrm{A}-\mathrm{F}=14.6$ ), but this was changed after the FTP testing was done.

\section{EGR Settings}

The particular EGR valve used required a GPO duty cycle of about $30 \%$ before it had much effect on the $\mathrm{NO}_{\mathrm{x}}$. As expected, increasing the EGR rate had an important effect on the $\mathrm{NO}_{\mathrm{x}}$ emissions, but at a certain value (which corresponded to a GPO duty cycle of about $40 \%$ ), the EGR started to have an adverse effect on the VOC emissions (see Figure 3). If the EGR rate (as represented by the GPO duty cycle) exceeded the value at which the VOC emissions started to increase, there was also a noticeable effect on the driveability of the vehicle because combustion instability. The VOC concentrations are shown as "propane equivalent" ppm because propane was used as the calibration $\mathrm{HC}$ as required by the CFR. To convert these values to carbon equivalents, the ppm values would have to be multiplied by three (because each propane molecule contains three carbon atoms).

\section{Initial Spark Advance Settings}

The effects of spark timing and EGR rates on engine-out $\mathrm{NO}_{\mathrm{x}}$ emissions are shown in Figure 4 at one particular speed and manifold pressure condition. The $\mathrm{NO}_{\mathrm{x}}$ emissions behaved as expected: their levels dropped as the EGR rate increased and as the spark advance decreased (Heywood 1988). As described earlier, the spark timing selected was the minimum spark advance for best torque. Once these spark settings were determined, they were programmed into the controller as being the baseline spark advance settings. The values used are shown in Figure 5.

\section{FTP Testing}

\section{Introduction}

We made two separate trips to the EPA laboratories for emission testing. The FTP involves driving the vehicle over a simulated urban trip on a chassis dynamometer. Figure 6 shows the driving cycle on speed-time coordinates. The FTP calls for the vehicle's engine to be at ambient temperature when the test is started and this essentially requires that the vehicle "soak" with the engine off for at least $12 \mathrm{~h}$. The vehicle preparation and soak requires a great deal of time, so only one such test can be conducted each day. 
The emissions are reported as a weighted average for two urban trips with the same speedtime profile, the difference being that one trip starts with the engine at ambient temperature and the other starts 10 min after the engine is shut down following completion of the first trip. The first cycle is sometimes referred to as the "cold" cycle and the second trip the "hot" cycle. Each trip, or cycle, is divided into a "transient" phase (the first $505 \mathrm{~s}$ of the cycle) and a "stabilized" phase (the remainder of the cycle). Four emissions determinations are made: the cold transient portion of the test (bag 1); the stabilized period of the cold-start test (bag 2); the hot-transient portion of the test (bag 3); and the stabilized period of the hot-start test. The stabilized period of the hot-start test is assumed to yield the same results as the stabilized period of the cold-start test and so is not actually run. Thus, the "hot" cycle involves running only the first $505 \mathrm{~s}$ of the driving cycle. The hot transient portion of the test is referred to as the hot 505 and very often develop- mental emissions testing involves running hot $505 \mathrm{~s}$. We used that approach to determine some of our operating parameters.

\section{The First Test Series}

The first series of tests conducted was with a single CNG-formulated catalyst (except as noted) installed where the stock 1991 SL1 catalyst was located. This was the same catalyst used in the previous study (Hodgson 1995). The results are given in Table 1, but to facilitate comparisons between the full FTP tests and the hot 505 tests, only the bag 3 results are given. The detailed results of these tests are presented in Appendix B.

The first test was a complete FTP with a slightly rich bias on the stoichiometry. Tests 2 and 3 were hot 505s in which we increased the commanded air-fuel ratio. The results show benefits for $\mathrm{CO}$ and $\mathrm{THCs}$, but an increase in the $\mathrm{NO}_{\mathrm{x}}$. In test four we attempted to decrease the $\mathrm{NO}_{\mathrm{x}}$ by increasing the EGR rate, which effectively decreased the $\mathrm{NO}_{\mathrm{x}}$. In test 5 we raised the controlled air-fuel ratio further, but the only effect was to raise the $\mathrm{NO}_{x}$ emissions. In test 6 we "tweaked" the EGR rate further, but it was already about as high as possible without introducing driveability problems, and the results showed no benefits. We decided to run a complete FTP the following day and to follow it up with a hot 505 without the catalyst on the car. These tests are test 7 and test 8 , respectively.

The results from the two complete FTP tests (tests 1 and 7) were higher than expected, and an examination of the results from test 8 indicated the reason. By taking the difference between the emissions from test 8 and test 7 and dividing this by the results from test 8 , we calculated the average catalyst efficiency during the bag 3 phase of the FTP cycle. The results are shown in Table 2. 


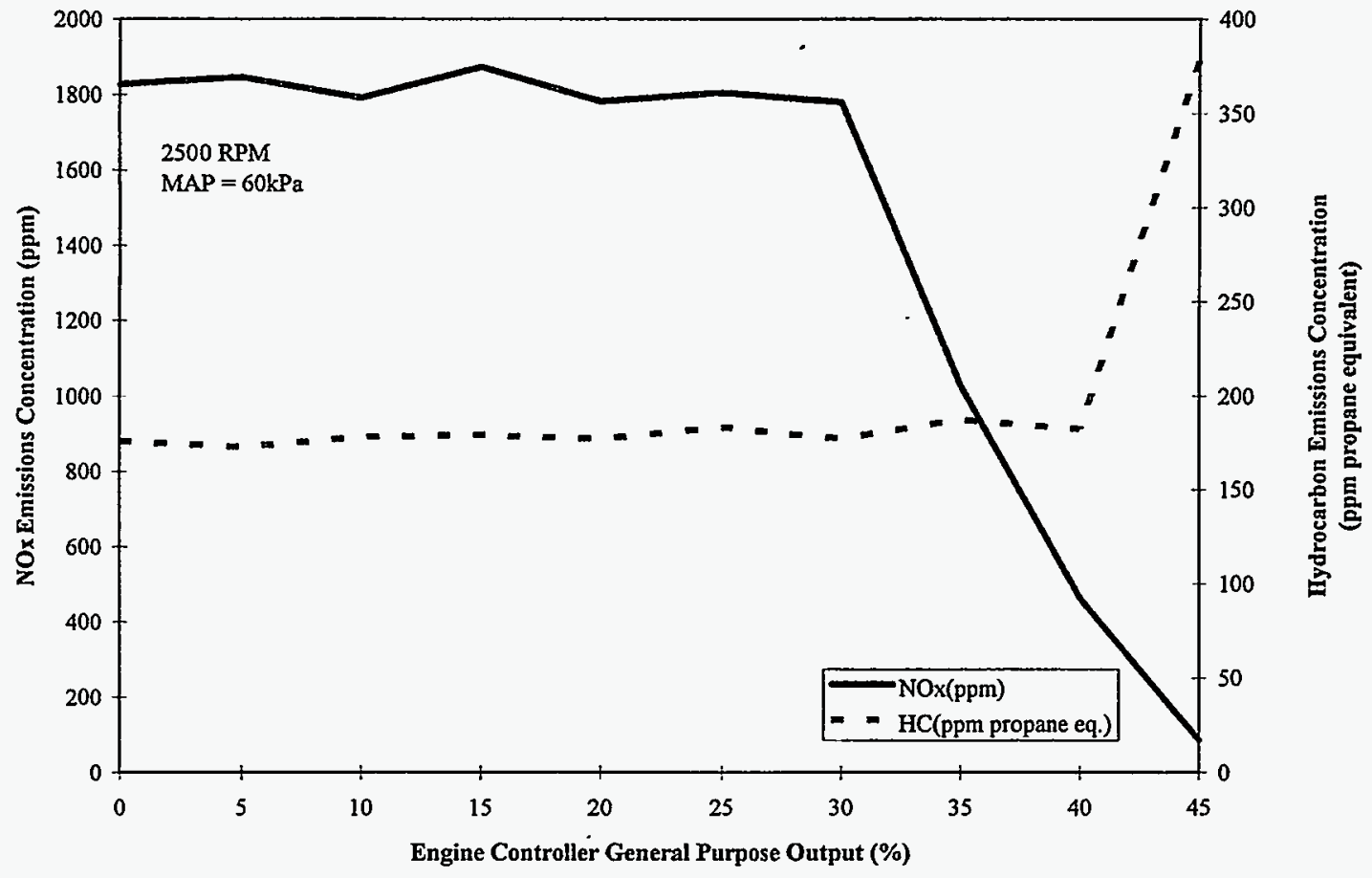

Figure 3. Engine-out emissions versus EGR rate

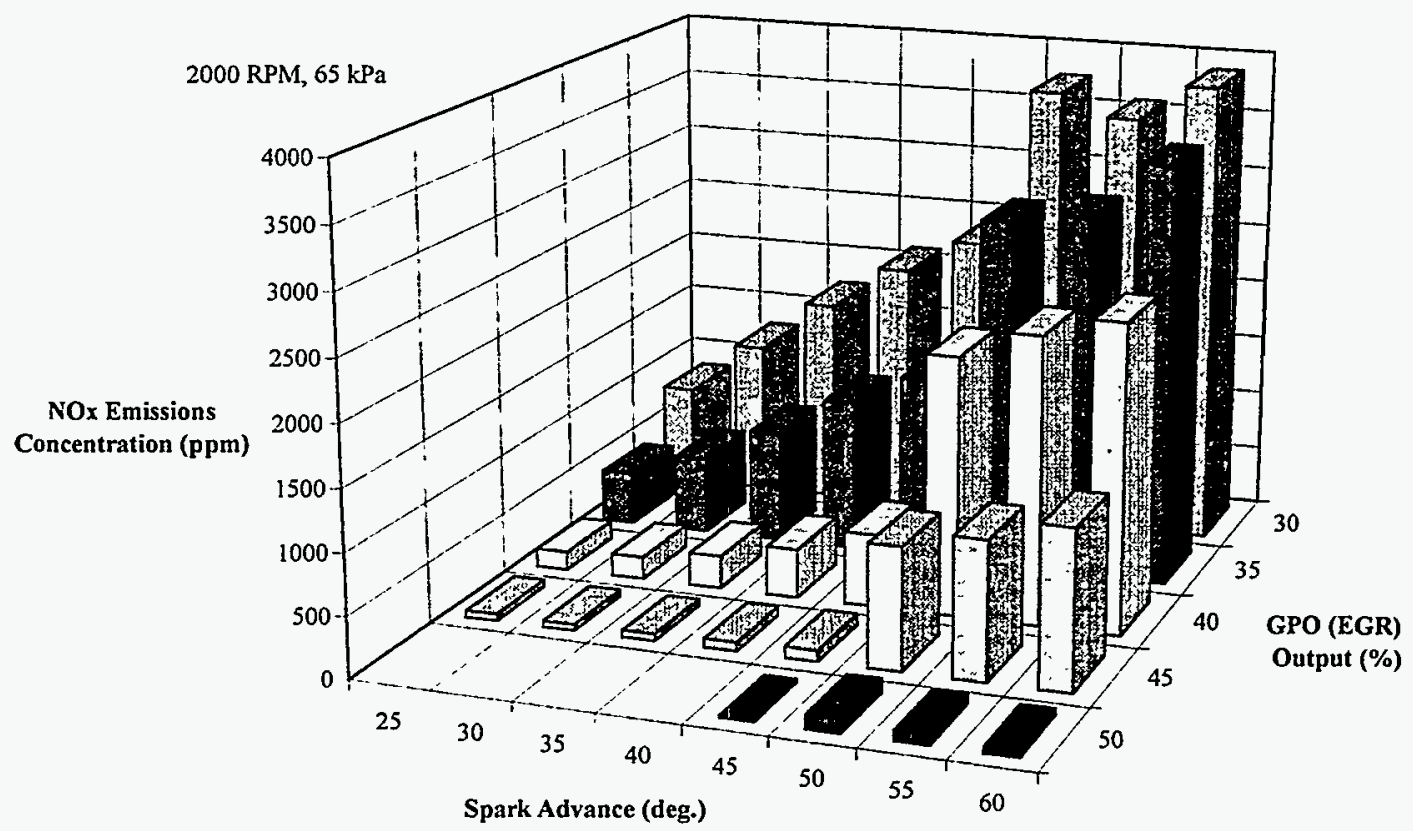

Figure 4. Engine-out emissions $\left(\mathrm{NO}_{x}\right)$ as a function of spark advance and GPO output (EGR) 


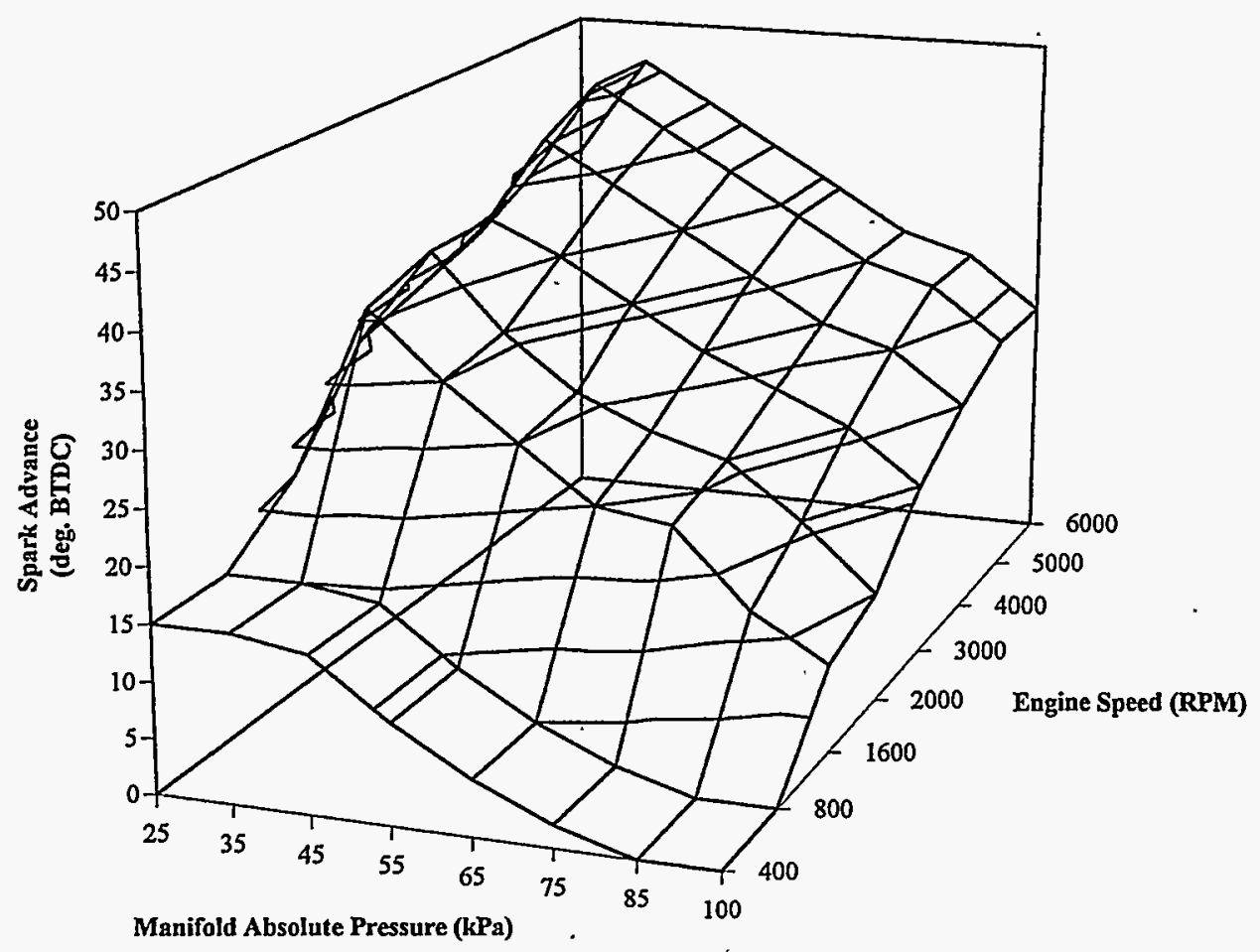

Figure 5. Spark advance as a function of engine speed and intake manifold pressure.

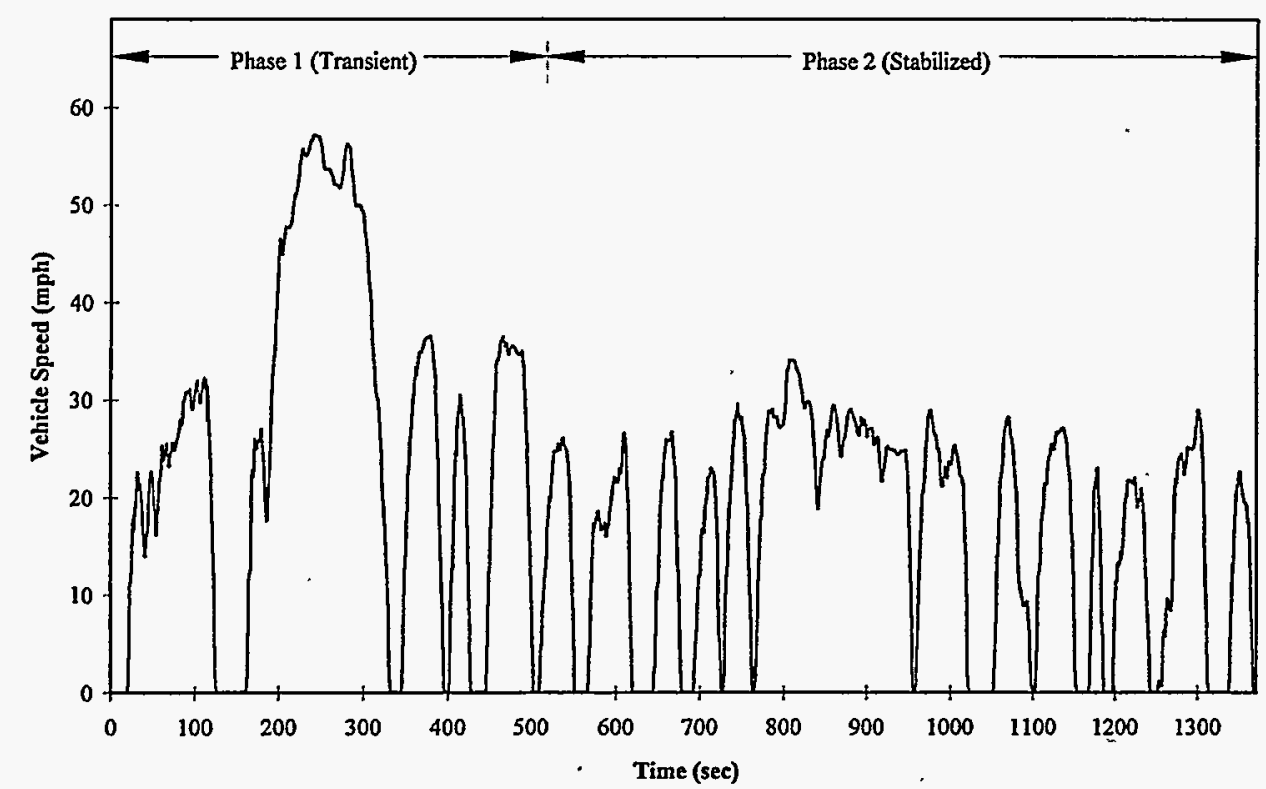

Figure 6. Specified vehicle speed versus time trace for FTP urban driving cycle 
Table 1. First Series of Emission Tests-Bag 3 Results Only

\begin{tabular}{|l|c|c|c|c|l|}
\hline \multicolumn{1}{|c|}{ Test Number } & $\begin{array}{c}\text { EPA Test } \\
\text { Number }\end{array}$ & \multicolumn{3}{|c|}{$\begin{array}{c}\text { Test Results-Bag 3 } \\
\text { (g/mi) }\end{array}$} & \multicolumn{1}{c|}{ Comments } \\
\hline & & THC & $\mathrm{NO}_{\mathrm{x}}$ & $\mathrm{CO}$ & \\
\hline 1 (Full FTP) & 32401 & 1.65 & 0.07 & 5.86 & Initial test (A/F=14.0) \\
\hline 2 (Hot 505) & 32402 & 1.05 & 0.25 & 2.98 & A/F=14.4 \\
\hline 3 (Hot 505) & 32403 & 0.99 & 0.35 & 1.85 & A/F=14.5 \\
\hline 4 (Hot 505) & 32404 & 1.02 & 0.22 & 1.66 & Increased EGR @ WOT \\
\hline 5 (Hot 505) & 32405 & 1.04 & 0.31 & 1.64 & A/F=14.58 \\
\hline 6 (Hot 505) & 32406 & 0.97 & 0.30 & 1.71 & Slight increase in EGR \\
\hline 7 (Full FTP) & 32407 & 0.92 & 0.34 & 1.33 & Same settings as 32406 \\
\hline 8(Hot 505) & 32408 & 2.94 & 0.94 & 10.38 & No catalyst \\
\hline
\end{tabular}

Table 2. Initial Catalyst Efficiency Values

\begin{tabular}{|c|c|}
\hline $\begin{array}{c}\text { Emission } \\
\text { Component }\end{array}$ & $\begin{array}{c}\text { Catalyst } \\
\text { Efficiency (\%) }\end{array}$ \\
\hline THC & 69 \\
\hline $\mathrm{NO}_{\mathrm{x}}$ & 64 \\
\hline $\mathrm{CO}$ & 87 \\
\hline
\end{tabular}

We concluded from these tests that

- The initial configuration as initially tested was not satisfactory

- The initial commanded air-fuel ratio gave the most promising $\mathrm{NO}_{\mathbf{x}}$ emissions results

- EGR significantly reduced $\mathrm{NO}_{\mathrm{x}}$

- The catalyst we were using was less efficient than we had anticipated.

We suspect that the catalyst deteriorated during the development testing on the chassis dynamometer because during the previous study (Hodgson 1995) the catalyst efficiency was much higher.

\section{The Second Test Series}

Following the first series of tests run we decided to incorporate a production close-coupled catalyst (used in the 1997 Saturns for the California market) into our vehicle. In the production vehicle this catalyst is used in conjunction with an under-floor main catalyst and we felt that its use was consistent with the original intent of the project to use production hardware to the extent possible. The under-floor catalyst, which had been used in the previous study (Hodgson 1995) and in the first test series of the present study, was replaced with a special catalyst that had originally been provided for the University of Tennessee's CNG-fueled GM pickup truck. The 
washcoat composition of this catalyst was formulated especially for natural gas use and is considered to be proprietary by the manufacturer, Engelhard Corporation. The catalyst used was a bolt-in replacement for the stock catalyst. The second series of tests is summarized in Table 3 . In order to make meaningful comparisons among the hot 505 tests and the full FTP tests, only the bag 3 results from the full FTP tests are given. The weighted results from test 13 are presented in Table 4, and the detailed emission test results for all the tests are given in Appendix B.

Table 3. Second Series of Emission Tests-Bag 3 Results Only

\begin{tabular}{|c|c|c|c|c|l|}
\hline Test Number & $\begin{array}{c}\text { EPA Test } \\
\text { Number }\end{array}$ & \multicolumn{3}{|c|}{ Test Results-Bag 3/ } & \multicolumn{1}{|c|}{ Vehicle Configuration } \\
\hline & & THC & $\mathrm{NO}_{\mathrm{x}}$ & $\mathrm{CO}$ & \\
\hline 9 (Full FTP) & 3432 & 0.14 & 0.03 & 0.68 & As delivered (A/F=14.0) \\
\hline 10 (Hot 505) & 3433 & 0.09 & 0.10 & 0.34 & No EGR (procedural error) \\
\hline 11 (Hot 505) & 3434 & 0.36 & 0.08 & 3.43 & Close-coupled catalyst only \\
\hline 12 (Hot 505) & 3435 & 0.02 & 0.11 & 0.05 & No EGR \\
\hline 13 (Full FTP) & 3436 & 0.14 & 0.04 & 0.34 & Reduced fuel rail pressure \\
\hline 14 (Hot 505) & 3437 & 0.09 & 0.09 & 0.10 & No EGR \\
\hline
\end{tabular}

Table 4. Emission Results Compared to ULEV Values

\begin{tabular}{|l|c|c|c|}
\hline & Test 13 & ULEV & ULEV/Test 13 \\
\hline RANMOG & 0.009 & 0.04 & 4.4 \\
\hline NO $_{x}$ & 0.043 & 0.20 & 4.7 \\
\hline$C O$ & 0.64 & 1.70 & 2.7 \\
\hline
\end{tabular}

Before the emission tests, the CNG tank was filled to about 2700 psig for the emission testing. As the gas was consumed, the fuel rail pressure dropped several psig as the tank pressure dropped. Because the mass flow rate through the injectors is a function of the fuel rail pressure, and because examination of the real-time emissions data showed that many VOC and $\mathrm{CO}$ emissions occurred while the controller was in open loop mode (no exhaust oxygen feedback), the fuel rail pressure was adjusted to 85 psig for test 13 (it was about 91 psig for run 9). The real-time results showed the expected benefit during the open loop operation. Again, the tests showed the relative effectiveness of the strategies employed. Test 13 represents the culmination of the testing.

Figures $7 \mathrm{a}, 7 \mathrm{~b}$, and $7 \mathrm{c}$ show the real-time emissions recorded from the dilution tunnel while test 13 was being conducted. The catalyst light-off is clearly discernible at the early stages of the bag 1 and bag 3 portions of the test. The $\mathrm{HC}$ and $\mathrm{CO}$ traces are out of phase because of the longer travel time taken by the sample in going to the $\mathrm{CO}$ analyzer; therefore, the relationships among the three components at a given instant of time should be interpreted carefully (Smith 1996). 


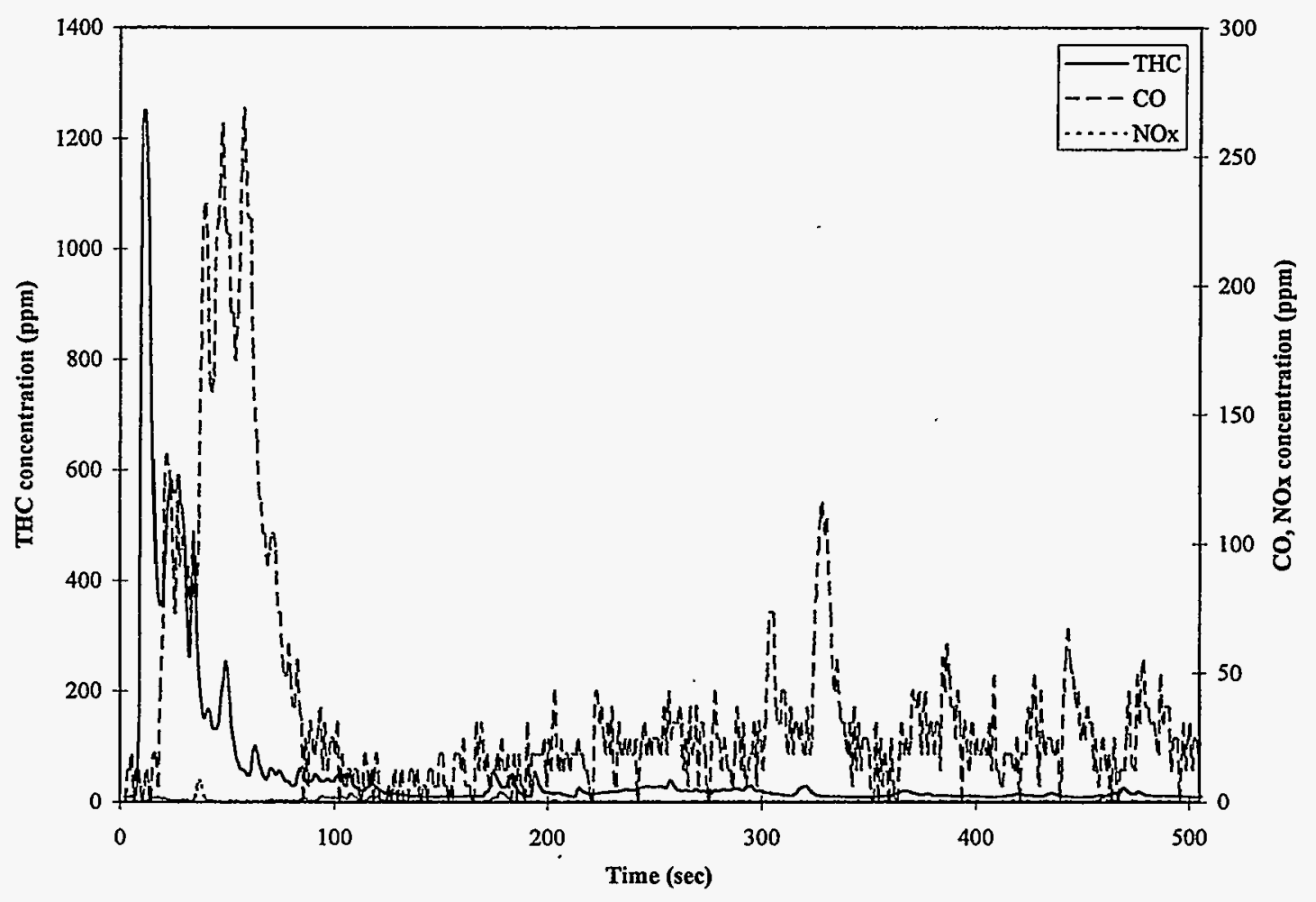

Figure 7a. Real-time emissions (Bag 1)

Bag 2(Stab.)

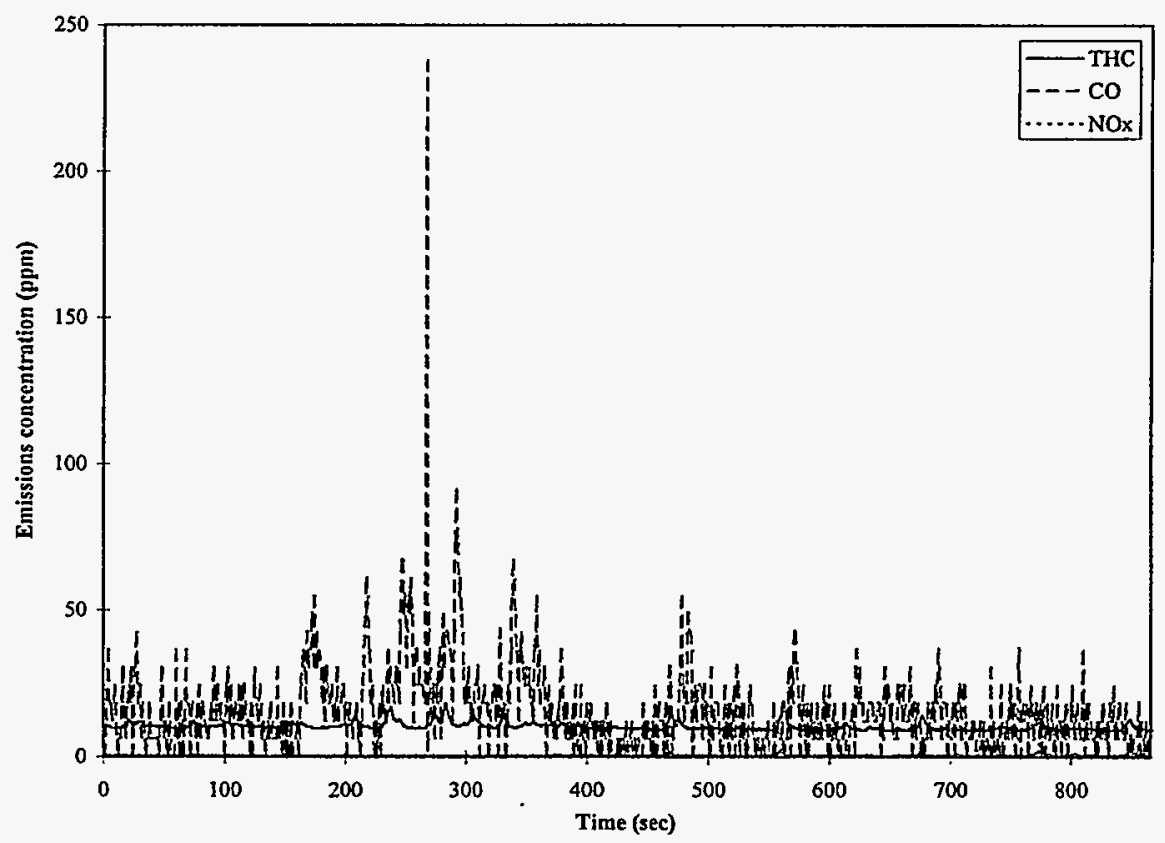

Figure 7b. Real-time emissions (Bag 2) 


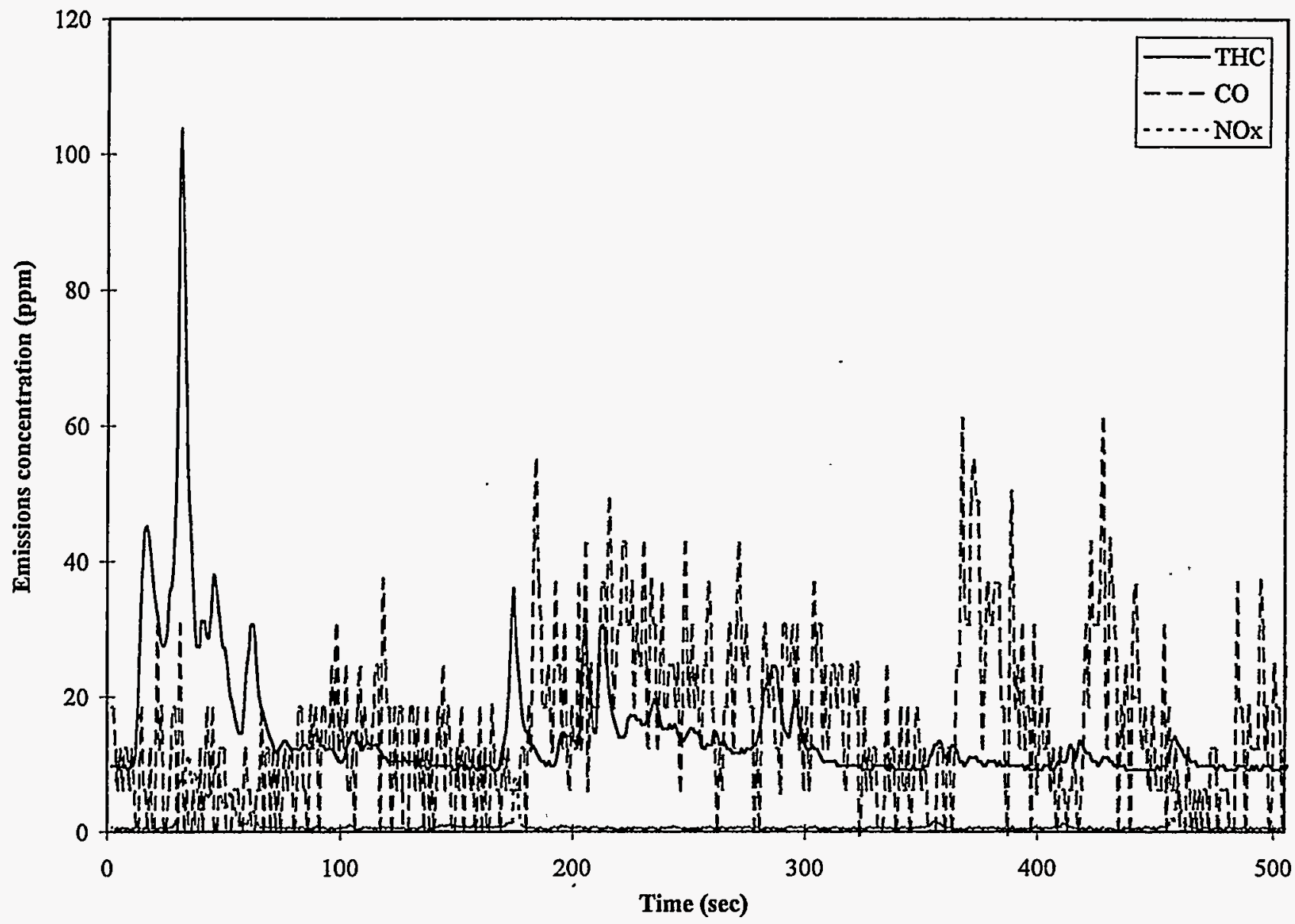

Figure 7c. Real-time emissions (Bag 3)

The results of these tests, compared to those from the previous round, show the tremendous influence that catalyst activity has on emission results. Because we could not operate the vehicle without the close-coupled catalyst (it was an integral part of the exhaust manifold), we could not determine the efficiency of the catalysts used in this second series of tests. Comparing the results of tests 9 and 11, however, gives an indication of the contribution made by the underfloor catalyst. This also shows that the close-coupled catalyst, although important, is not sufficient to reduce the emissions to the desired levels. The big advantage of the close-coupled catalyst is faster light-off.

\section{Interpreting the Final Results}

Reporting the results from standard emission tests on vehicles fueled with gasoline is relatively straightforward. When the fuel is $\mathrm{CNG}$, however, several factors must be considered. These involve the response of the flame ionization detector (FID) to methane, the calculation of the mass of the THCs, the calculation of the non-methane hydrocarbons, and the calculation of the RANMOGs. To do this correctly is fairly involved and requires speciation of the VOC emitted and determination of the aldehydes present. 
The results for VOC shown in Tables 1 and 3 need some explanation. In essence, the values are reported as THCs in that they are calculated using the EPA procedures for gasoline-fueled vehicles. The concentration values are not corrected for the FID response to methane (the FID used at the EPA laboratory has a response factor of 1.17 , which means that if the true methane concentration were $100 \mathrm{ppm}$ the FID would report it as $117 \mathrm{ppm}$ ). On the other hand, when the mass of the VOC was reported, the density used for the VOC was based on an average $\mathrm{HC}$ mix that has a molecular weight of 13.85 , whereas methane has a molecular weight of 16 . The VOC in the exhaust are not $100 \%$ methane, but the methane content is usually very high (particularly when the fuel used is high in methane), and the exhaust VOCs are primarily methane. Thus, the mass of the VOCs should be calculated using the molecular weight of methane. The speciated results for test 13 are discussed below and show that methane was responsible for almost 95\% (by mass) of the exhaust HCs. Fortunately, the corrections for the FID response and the molecular weight of the VOCs essentially cancel out.

The California Air Resources Board (CARB) has ruled that the NMOG exhaust emissions can be adjusted for reactivity before they are compared to the applicable standards. Using this approach, the results from emission test 13 are compared with the ULEV targets in Table 4 . The details of the approach used are contained in Appendix C.

These results were obtained with essentially new catalysts. Some deterioration in the emissions will certainly occur as the catalysts age.

\section{Speciating VOCs}

The VOC emissions from test 13 were speciated using gas chromatography (GC) to determine the mix of HCs present in the exhaust.

\section{Hydrocarbon Species}

Hydrocarbons are compounds that contain only carbon and hydrogen. Ninety-three HC species were identified and quantified, only seven of which contributed individually more than $0.1 \%$ of the THCs present (by mass). The breakdown is shown in Table 5. The species listed represent $98.44 \%$ of the HCs present by mass. Clearly, methane dominates the mix, which is typical when natural gas is used as the fuel.

\section{Aldehydes}

Aldehydes were determined by collecting exhaust samples with 2,4-dinitro phenylhydrazine (DNPH) in impingers and subsequent analysis with high performance liquid chromatography (HPLC). The weighted total aldehydes were $3.94 \mathrm{mg} / \mathrm{mi}$; formaldehyde had the largest contribution to this mix. The breakdown of aldehydes is shown in Table 6. 
Table 5. Major Hydrocarbon Species Present (Test 13)

\begin{tabular}{|l|c|c|}
\hline \multicolumn{1}{|c|}{ Compound Name } & $\begin{array}{c}\text { Weighted Emissions } \\
(\mathbf{m g} / \mathbf{m i})\end{array}$ & $\begin{array}{c}\text { Percent of Total } \\
\text { (by mass) }\end{array}$ \\
\hline Methane & 248.2 & 94.61 \\
\hline Ethylene & 1.620 & 0.62 \\
\hline Ethane & 7.066 & 2.69 \\
\hline Iso-butylene & 0.301 & 0.11 \\
\hline Methylcyclopentane & 0.398 & 0.15 \\
\hline 2,4 Dimethylpentane & 0.292 & 0.11 \\
\hline 1-Nonane & 0.395 & 0.15 \\
\hline
\end{tabular}

Table 6. Breakdown of Aldehydes (Test 13)

\begin{tabular}{|l|c|c|}
\hline \multicolumn{1}{|c|}{ Compound } & $\begin{array}{c}\text { Weighted Mass } \\
\text { Emissions (mg/mi) }\end{array}$ & $\begin{array}{c}\text { Percent of Total Aldehydes } \\
\text { (by mass) }\end{array}$ \\
\hline Formaldehyde & 2.89 & 73.48 \\
\hline Acetaldehyde & 0.74 & 18.82 \\
\hline Acrolein & 0.14 & 3.44 \\
\hline Propionaldehyde & 0.09 & 2.35 \\
\hline Hexanaldehyde & 0.03 & 0.67 \\
\hline 2-Butanone & 0.05 & 1.25 \\
\hline & 3.94 & 100.00 \\
\hline
\end{tabular}

\section{Toxics}

One well-known advantage of natural gas over conventional petroleum fuels is the low level of exhaust toxics emitted. The EPA lists the following as exhaust toxics to be considered when evaluating reformulated gasolines: benzene, 1,3-butadiene, formaldehyde, acetaldehyde, and polycyclic organic matter. Table 7 gives the values measured in this study.

\section{Ozone-Forming Potential}

Using the speciated VOC results coupled with the maximum incremental reactivity (MIR) for each specie allows the calculation of the ozone-forming potential (OFP) and the specific reactivity (SR) of the exhaust emissions from the vehicle. The MIR values used were provided by the EPA in the form of a spreadsheet that gives the MIR expressed as the mass of ozone per unit mass of the specie considered. To calculate the OFP one multiplies the MIR for a particular specie by the mass emissions of that specie and then adds up the contributions for all the species.

This approach gave the values shown in Table 8. Several values are shown to facilitate comparisons with other results. 
Table 7. Exhaust Toxics (Test 13)

\begin{tabular}{|l|c|}
\hline \multicolumn{1}{|c|}{ Toxic } & $\begin{array}{c}\text { Weighted Mass } \\
\text { Emissions } \\
\text { (mg/mi) }\end{array}$ \\
\hline Benzene & 0.16 \\
\hline 1,3-Butadiene & none detected \\
\hline Formaldehyde & 2.89 \\
\hline Acetaldehyde & 0.74 \\
\hline Total Toxics & 3.79 \\
\hline
\end{tabular}

Table 8. Ozone-Forming Potential of Exhaust Emissions

\begin{tabular}{|l|l|}
\hline \multicolumn{1}{|c|}{ Contributions } & \multicolumn{1}{c|}{ OFP $_{\text {MIR }}\left(\mathrm{gO}_{3}\right.$ /mile) } \\
\hline Total & 0.098 \\
\hline Methane & 0.004 \\
\hline Ethylene & 0.012 \\
\hline Formaldehyde & 0.021 \\
\hline Carbon Monoxide & 0.035 \\
\hline NMOG & 0.059 \\
\hline
\end{tabular}

The results show that although the ozone-forming potential calculated using this approach is quite low (see discussion below), the contributions made by the various species is of interest. For example, the largest contribution is due to $\mathrm{CO}$. The last row in the table gives the most commonly reported value; namely, the OFP of the NMOGs only. Because of this vehicle's low organic emissions, this figure is only about one-half the total.

Another figure that is often reported is the SR of the exhaust. This is found by dividing the OFP of the NMOG by the mass of the NMOG. In this particular case the specific reactivity is 3.28 grams of ozone per gram of NMOG. As will be seen later, the SR of the NMOG is not significantly different from that from a vehicle fueled with RFG.

\section{Summary of FTP Test 13 Results}

In summary, the results from test 13 show the very low emissions obtained from this vehicle. The breakdown of the exhaust VOC emissions reveals the following (in terms of the weighted results in $\mathrm{g} / \mathrm{mi}$, except as noted otherwise):

$\begin{array}{ll}\text { THC (FID) } & 0.289 \\ \text { HC (GC) } & 0.276 \\ \text { Methane (GC) } & 0.262 \\ \text { NMHC } & 0.014 \\ \text { Aldehydes } & 0.004 \\ \text { NMOG } & 0.018\end{array}$




$\begin{array}{ll}\text { RANMOG } & 0.009 \\ \text { Total VOC } & 0.280 \\ \text { Total Toxics } & 0.004 \\ \text { NMOG SR } & 3.28 \mathrm{gO}_{3} / \mathrm{gNMOG} \\ \text { OFP }_{\mathrm{MR}}\left(\mathrm{gO}_{3} / \text { mile }\right) & 0.098\end{array}$

To put these values in perspective, the results from a $0.4 \mathrm{~g} / \mathrm{mi} \mathrm{NO}_{\mathrm{x}}$ California calibrated 1990 Ford Taurus operating on RFG (Siegel 1996) are shown in Table 9. The Taurus had accumulated about 6,300 miles at the start of testing and the results shown are the average of four FTP tests.

\section{Additional Reductions}

Although the emissions levels achieved are well below the ULEV values, which are applied at 50,000 miles or 100,000 miles, we noticed when we were fitting the close-coupled catalyst to the engine that there was evidence (based on the color of the exhaust ports) of variations in the cylinder-to-cylinder stoichiometry. We believe this may have been caused by the high levels of EGR used and the way the EGR is fed into the engine's intake manifold. Because the exhaust gas oxygen sensor signals the engine controller to adjust the oxygen level in the mixed exhaust from all four cylinders, the controller will supply fuel to all the cylinders in sufficient quantity to cause the leanest cylinder to approach stoichiometric conditions. This means that if there are variations in the air distribution to the cylinders, or if there is a mismatch in the flow characteristics of the injectors, there will be cylinders that run rich. One way to overcome this is to have an engine controller that controls each cylinder by the use of individual oxygen sensors on each cylinder. Clearly there are cost considerations associated with the implementation of such a system.

Table 9. Comparison of RFG and CNG Vehicle Emissions

\begin{tabular}{|c|c|c|}
\hline $\begin{array}{c}\text { Emission of } \\
\text { Interest }\end{array}$ & $\begin{array}{c}\text { RFG Taurus } \\
\text { (g/mi) }\end{array}$ & $\begin{array}{c}\text { CNG Saturn } \\
\text { (g/mi) }\end{array}$ \\
\hline $\mathrm{THC}$ & 0.22 & 0.28 \\
\hline $\mathrm{CO}$ & 2.57 & 0.64 \\
\hline $\mathrm{NO}_{\mathrm{x}}$ & 0.17 & 0.04 \\
\hline Toxics & 0.009 & 0.004 \\
\hline $\mathrm{NMOG}$ & 0.212 & 0.018 \\
\hline Total VOCs & 0.25 & 0.28 \\
\hline $\mathrm{SR}\left(\mathrm{gO}_{3} / \mathrm{gNMOG}\right)$ & 3.57 & 3.28 \\
\hline OFP (gO (mi) $^{\star}$ & 0.90 & 0.098 \\
\hline
\end{tabular}




\section{Performance Tests}

\section{Introduction}

Although performance testing was not the primary focus of this study, whenever gaseous fuels are used to replace liquid fuels, engine torque will probably decrease somewhat because of the decreased volumetric efficiency of the engine. This decrease in the volumetric efficiency is caused by the gaseous fuel displacing part of the air normally drawn into the engine. This, in turn, decreases the engine torque at wide-open throttle. Often an attempt is made to recover part of the lost torque capacity by raising the engine's compression ratio (the high octane rating of the natural gas normally raises the knock-limited compression ratio compared to gasoline).

Although we used this approach by using "flat-top" pistons in place of the stock pistons, we had some concern that this change might alter the combustion characteristics of the Saturn engine.

\section{Approach}

The approach we took was to compare the acceleration capability of a stock gasoline-fueled 1991 Saturn SL1 equipped with a five-speed manual transmission with that of the test vehicle. We took both vehicles to a local airport and ran wide-open throttle acceleration tests in first through fourth gear. We started the acceleration runs with the vehicle moving at the lowest speed that would normally be used in the gear selected and then pushed the accelerator to the wide-open position. We felt that this approach eliminated driver effects that often accompany standing start acceleration tests that involve possible wheel spin and gear shifting techniques. The vehicle speed was measured using a Davit Lightspeed noncontact (optical) speed sensor that we attached to the outside surface of the vehicle. We recorded the speed-time data using a Flight Recorder made by Advanced Electronic Diagnostics.

The vehicle weights (without driver and passenger) were within 150 pounds of each other $(2,340$ for the gasoline version and 2,480 for the $C N G$ version). The vehicles were tested with no attempt to equalize their weights because the difference in weights was associated with the conversion used (this difference was primarily associated with the weight of the fuel tank in the CNG vehicle).

\section{Results}

The speed-time results are shown in figures in Appendix D. The slopes of the curves indicate the acceleration, and for a given gear there is fairly constant acceleration at wide-open throttle for both the gasoline and the CNG vehicles. This is attributed to the relatively flat torque curve of the Saturn engine. We fitted straight lines to the data and calculated the average acceleration in each gear. The results, shown in Figure 8, indicate clearly that the use of CNG and the steps taken to achieve low emissions had a measurable effect on the acceleration capability of the vehicle. 


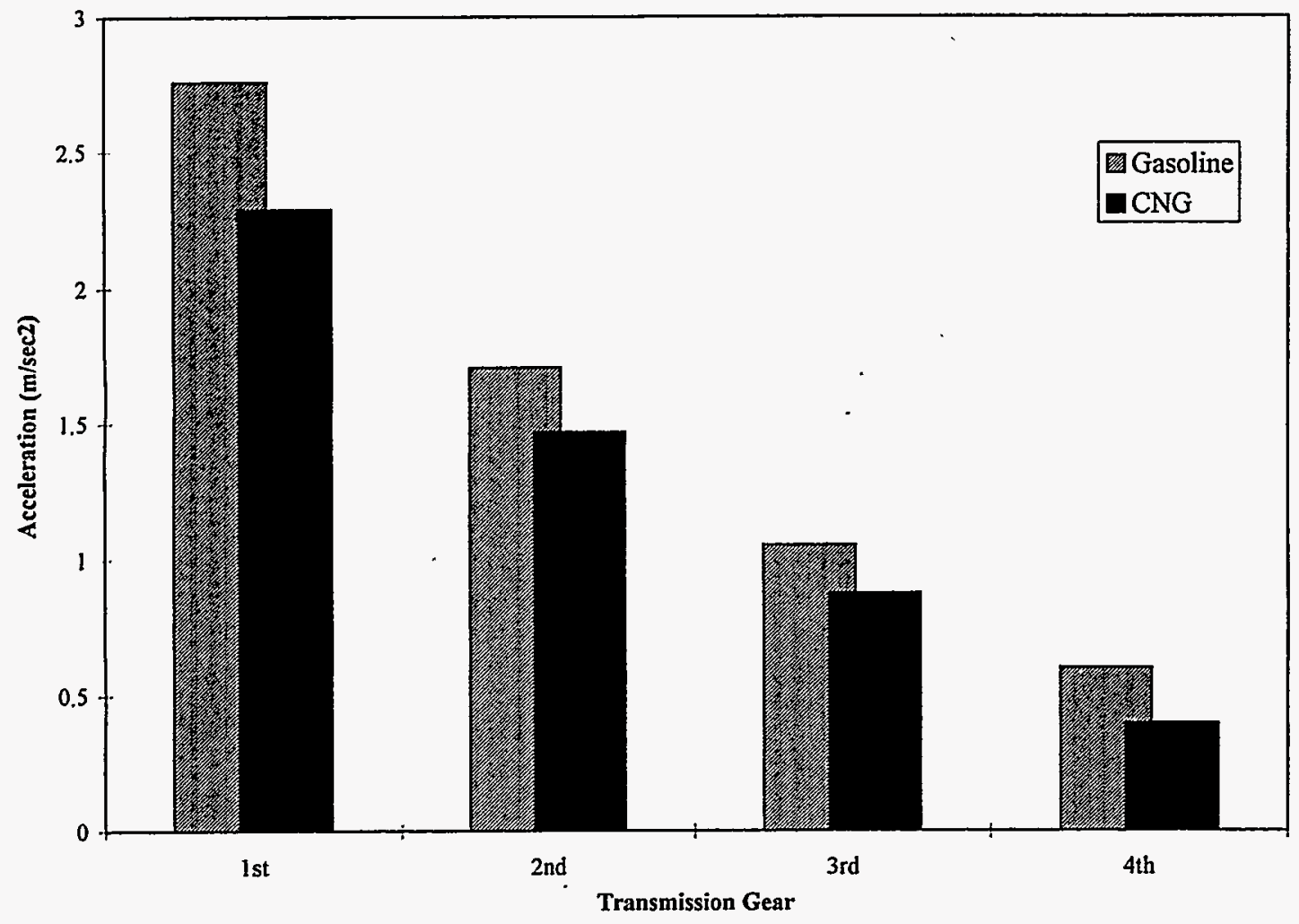

Figure 8. Vehicle acceleration comparison-CNG versus Gasoline

\section{Conclusions}

Based on the results of the study we reached the following conclusions (new catalysts were installed):

- Extremely low (less than $40 \%$ of the ULEV values) regulated exhaust emission levels were achieved

- The $\mathrm{NO}_{x}$ emissions achieved were less than one-fourth of the ULEV-specified value

- Toxic exhaust emissions were significantly lower than those associated with the use of RFG

- Careful control of mixture stoichiometry, spark timing, and EGR rates is required to achieve low emissions

- The use of a close-coupled catalyst in conjunction with a main catalyst formulated for natural gas emissions was required to achieve the results obtained.

This study also revealed some areas for further investigation if related work is done:

- Because the fuel rail pressure is an important variable affecting open loop emissions, the pressure regulator must deliver a fuel pressure that is unaffected by the fuel tank pressure. 
- At the very low exhaust emission rates achieved, factors that may not play important roles in achieving higher emission rates start to become important. In this study, fuel rail pressure and variations in air distribution to the engine cylinders were identified as two such important variables.

\section{Bibliography}

Brown, P. (ed.). 1996. "Simple, Light Conversion Leads to Geo Metro ULEV," CATF Review, Issue No. 27, Centre for Alternative Transportation Fuels, BCRI, Vancouver, October.

Cheng, W.K., et al. 1996. "An Overview of Hydrocarbon Emissions Mechanisms in SparkIgnition Engines," SAE Paper Number 932708, Society of Automotive Engineers.

Code of Federal Regulations (CFR), Title 40, Part 86, Superintendent of Documents, Washington. (Also available on the Environmental Protection Agency home page at www.epa.gov.)

Heywood, J.B. 1988. Internal Combustion Engine Fundamentals, McGraw-Hill Book Company, New York.

Hodgson, J.W.; E.N. Luton; and S.R. Lampley. 1995. "Development of a Dedicated CNG Compact Car," SAE Paper Number 952439, Society of Automotive Engineers.

Kim, J.W. et al. 1994. "Development of the Daewoo Dedicated Light Duty NGVII," in Proceedings of the Fourth Biennial International Conference and Exposition on Natural Gas Vehicles, International Association for Natural Gas Vehicles.

Lampley, S.R. 1995. The Evaluation of a Dedicated Natural Gas Vehicle Conversion, Master of Science Thesis, The University of Tennessee, Knoxville.

Matsuura, H. 1994. "Research and Development of Dedicated Compressed Natural Gas (CNG) Passenger Vehicle," in Proceedings of the Fourth Biennial International Conference and Exposition on Natural Gas Vehicles, International Association for Natural Gas Vehicles.

Matthews, R.D. et al. 1996. "The Texas Project: Part 1-Emissions and Fuel Economy of Aftermarket CNG and LPG Conversions of Light-Duty Vehicles," SAE Paper Number 962098, Society of Automotive Engineers.

Siegl, W.O. et al. 1996. "A Comparison of the Emissions from a Vehicle in Both Normal and Selected Malfunctioning Operation Modes," SAE Paper Number 961903, Society of Automotive Engineers. 
Smith, D.E. 1996. On the Reconstruction of Transient Automotive Emissions: An Application of Generalized Predictive Control Theory, Master of Science Thesis, The University of Tennessee, Knoxville.

Stone, R. 1994. Introduction to Internal Combustion Engines (Second Edition), Society of Automotive Engineers.

Weaver, C.S. 1989. "Natural Gas Vehicles-A Review of the State of the Art," SAE Paper Number 89133, Society of Automotive Engineers.

Wozniak, J.J. J.W. Acker; and R.J. Hidebrand. 1996. "Advanced Natural Gas Vehicle Program," in Preprints of the Annual Automotive Technology Development Customers" Coordination Meeting-Volume II: Automotive R\&D Poster Session, U.S. Department of Energy. 


\section{Appendix A}

\section{Composition of Natural Gas in Knoxville}

The composition of the natural gas in Knoxville is very stable. The table below gives the composition as reported by Lampley (1995).

Table A1. Composition of Natural Gas in Knoxville

\begin{tabular}{|l|c|}
\hline \multicolumn{1}{|c|}{ Component } & Mole Percent \\
\hline Methane & 96.18 \\
\hline Hexane & 0.062 \\
\hline Propane & 0.453 \\
\hline I-Butane & 0.059 \\
\hline N-Butane & 0.097 \\
\hline I-Pentane & 0.033 \\
\hline N-Pentane & 0.028 \\
\hline Carbon Dioxide & 0.460 \\
\hline Ethane & 2.212 \\
\hline Nitrogen & 0.416 \\
\hline \multicolumn{2}{|c|}{ Total } \\
\hline
\end{tabular}




\section{Appendix B}

\section{Detailed Emission Test Reports}


RUN NUMBER 1

EPA RUN $=32401$

CYCLE $=$ FTP $\quad$ TEST DATE $=10 / 8 / 96 \quad 8: 12$

FUEL

EPA VEHICLE ID

CNG1

ODOMETER READING

SA420G

22278.0

\begin{tabular}{|c|c|c|c|c|}
\hline & BAG 124 & BAG 1 & BAG 2 & BAG 3 \\
\hline $\begin{array}{l}\text { VMIX CUBIC FEET } \\
\text { DILUTION FACTOR } \\
\text { FUEL ECON. MILES/GAL } \\
\text { TEST DIST. MILES }\end{array}$ & $\begin{array}{r}1320.00 \\
24.77 \\
20.24 \\
0.67\end{array}$ & $\begin{array}{r}5336.00 \\
24.10 \\
25.60 \\
3.59\end{array}$ & $\begin{array}{r}9184.00 \\
37.80 \\
26.91 \\
3.89\end{array}$ & $\begin{array}{r}5318.00 \\
29.04 \\
31.41 \\
3.59\end{array}$ \\
\hline $\begin{array}{l}\text { HC PPM } \\
\text { HC GRAMS } \\
\text { HC GRAMS/MILE }\end{array}$ & $\begin{array}{r}486.00 \\
10.48 \\
15.57\end{array}$ & $\begin{array}{r}171.02 \\
14.90 \\
4.15\end{array}$ & $\begin{array}{r}20.81 \\
3.12 \\
0.80\end{array}$ & $\begin{array}{r}68.14 \\
5.92 \\
1.65\end{array}$ \\
\hline $\begin{array}{l}\text { NOX PPM } \\
\text { NOX GRAMS } \\
\text { NOX GRAMS/MILE }\end{array}$ & $\begin{array}{l}4.80 \\
0.32 \\
0.47\end{array}$ & $\begin{array}{l}1.40 \\
0.38 \\
0.10\end{array}$ & $\begin{array}{l}0.70 \\
0.32 \\
0.08\end{array}$ & $\begin{array}{l}1.00 \\
0.27 \\
0.07\end{array}$ \\
\hline $\begin{array}{l}\text { CO PPM } \\
\text { CO GRAMS } \\
\text { CO GRAMS/MILE }\end{array}$ & $\begin{array}{r}392.00 \\
17.06 \\
25.35\end{array}$ & $\begin{array}{r}178.00 \\
31.32 \\
8.72\end{array}$ & $\begin{array}{r}66.00 \\
19.98 \\
5.14\end{array}$ & $\begin{array}{r}120.00 \\
21.04 \\
5.86\end{array}$ \\
\hline $\begin{array}{l}\mathrm{CO} 2 \% \\
\mathrm{CO} 2 \text { GRAMS } \\
\mathrm{CO} 2 \text { GRAMS/MILE }\end{array}$ & $\begin{array}{r}0.25 \\
171.61 \\
255.00\end{array}$ & $\begin{array}{r}0.31 \\
868.06 \\
241.80\end{array}$ & $\begin{array}{r}0.20 \\
947.79 \\
243.65\end{array}$ & $\begin{array}{r}0.27 \\
731.66 \\
203.80\end{array}$ \\
\hline
\end{tabular}

** WEIGHTED VALUES **

FUEL ECON.

FUEL ECON.

$\mathrm{HC}$

NOX

$\mathrm{CO}$

$\mathrm{CO} 2$

OMHCE
MILES/GAL.

BTU/MILE

GRAMS/MILE

GRAMS/MILE

GRAMS/MILE

GRAMS/MILE

GRAMS/MILE
27.7062

4630.8664

1.7249

0.0851

6.0753

232.3666

1.7249 (ALDEHYDES ABSENT) 
RUN NUMBER 2

EPA RUN $=32402$

CYCLE $=$ HOT $505 \quad$ TEST DATE $=10 / 9 / 96 \quad 10: 20$

FUEL

CNG1

EPA VEHICLE ID

SA420G

ODOMETER READING

22299.0

REGULATED EMISSIONS REPORT RE32

BAG 1

VMIX CUBIC FEET

5322.00

DILUTION FACTOR

29.51

FUEL ECON. MILES/GAL

31.63

TEST DIST. MILES

3.59

HC PPM

43.56

HC GRAMS

3.79

HC GRAMS/MILE

1.05

\section{NOX PPM}

3.50

NOX GRAMS

0.90

NOX GRAMS/MILE

0.25

\begin{tabular}{lr}
\hline & \\
CO PPM & 61.00 \\
CO GRAMS & 10.70 \\
CO GRAMS/MILE & 2.98 \\
\hline & \\
\hline & \\
CO2 \% & 0.27 \\
CO2 GRAMS & 748.40 \\
\hline
\end{tabular}

** WEIGHTED VALUES **

FUEL ECON.

FUEL ECON.

$\mathrm{HC}$

NOX

$\mathrm{CO}$

$\mathrm{CO} 2$

OMHCE
MILES/GAL.

BTU/MILE

GRAMS/MILE

GRAMS/MILE

GRAMS/MILE

GRAMS/MILE

GRAMS/MILE
31.6304

4056.3323

1.0546

0.2500

2.9815

208.4687

1.0546 (ALDEHYDES ABSENT) 
RUN NUMBER 3

EPA RUN $=32403$

$$
\text { CYCLE }=\text { HOT505 }
$$

TEST DATE $=10 / 9 / 96$

$10: 35$

FUEL

CNG1

EPA VEHICLE ID

SA420G

ODOMETER READING

22306.0

$* * * * * * * * * * * * * * * * * * * * * * * * * * * * * * * * * * * * * * * * * * * * * * * * *$

REGULATED EMISSIONS REPORT RE32

$* * * * * * * * * * * * * * * * * * * * * * * * * * * * * * * * * * * * * * * * * * * * * * * * *$

BAG 1

VMIX CUBIC FEET

DILUTION FACTOR

5303.00

31.52

35.03

FUEL ECON. MILES/GAL

3.59

TEST DIST. MILES

41.24

HC PPM

3.57

HC GRAMS

0.99

HC GRAMS/MILE

4.90

NOX PPM

1.25

NOX GRAMS

0.35

NOX GRAMS/MILE

38.00

CO PPM

6.64

CO GRAMS

1.85

CO GRAMS/MILE

$\mathrm{CO} 2 \%$

CO2 GRAMS

189.43

CO2 GRAMS/MILE

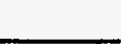

** WEIGHTED VALUES **

FUEL ECON.

FUEL ECON.

$\mathrm{HC}$

NOX

$\mathrm{CO}$

$\mathrm{CO} 2$

OMHCE
MILES/GAL.

BTU/MILE

GRAMS/MILE

GRAMS/MILE

GRAMS/MILE

GRAMS/MILE

GRAMS/MILE
35.0317

3662.5006

0.9949

0.3488

1.8507

189.4332

0.9949 (ALDEHYDES ABSENT) 
RUN NUMBER 4

\begin{tabular}{|c|c|c|}
\hline EPA RUN = 32404 & CYCLE $=$ HOT505 & TEST DATE $=10 / 9 / 96$ \\
\hline FUEL & $\mathrm{CNGI}$ & \\
\hline EPA VEHICLE ID & SA420G & \\
\hline ODOMETER READING & 22310.0 & \\
\hline
\end{tabular}

REGULATED EMISSIONS REPORT RE32

BAG 1

VMIX CUBIC FEET

5302.00

DILUTION FACTOR

29.23

FUEL ECON. MILES/GAL

31.08

TEST DIST. MILES

3.59

$\begin{array}{lr}\text { HC PPM } & 42.14 \\ \text { HC GRAMS } & 3.65 \\ \text { HC GRAMS/MILE } & 1.02\end{array}$

NOX PPM

2.90

NOX GRAMS

0.78

NOX GRAMS/MILE

0.22

CO PPM

34.00

CO GRAMS

5.94

CO GRAMS/MILE

1.66

\begin{tabular}{lr} 
CO2 \% & 0.28 \\
CO2 GRAMS & 770.07 \\
CO2 GRAMS/MILE & 214.50 \\
\hline
\end{tabular}

** WEIGHTED VALUES **

FUEL ECON.

FUEL ECON.

$\mathrm{HC}$

NOX

$\mathrm{CO}$

$\mathrm{CO} 2$

OMHCE
MILES/GAL.

BTU/MILE

GRAMS/MILE

GRAMS/MILE

GRAMS/MILE

GRAMS/MILE

GRAMS/MILE
31.0772

4128.5415

1.0162

0.2166

1.6556

214.5037

1.0162 (ALDEHYDES ABSENT) 
RUN NUMBER 5

EPA RUN $=32405$

$$
\text { CYCLE }=\text { HOT505 }
$$

TEST DATE $=10 / 9 / 96$

$2: 20$

FUEL

EPA VEHICLE ID

CNG1

ODOMETER READING

SA420G

22321.0

REGULATED EMISSIONS REPORT RE32

BAG 1

VMIX CUBIC FEET

DILUTION FACTOR

5268.00

29.22

31.58

FUEL ECON. MILES/GAL

3.59

TEST DIST. MILES

43.33

HC PPM

3.73

HC GRAMS

1.04

HC GRAMS/MILE

4.40

NOX PPM

1.12

NOX GRAMS

0.31

NOX GRAMS/MILE

34.00

CO PPM

CO GRAMS

5.91

CO GRAMS/MILE

1.64

\begin{tabular}{lr}
$\mathrm{CO} 2 \%$ & 0.28 \\
CO2 GRAMS & 757.22 \\
CO2 GRAMS/MILE & 210.93 \\
\hline
\end{tabular}

** WEIGHTED VALUES **

FUEL ECON.

MILES/GAL.

31.5848

FUEL ECON.

BTU/MILE

GRAMS/MILE

4062.1956

1.0384

NOX

$\mathrm{CO}$

GRAMS/MILE

0.3117

GRAMS/MILE

1.6449

$\mathrm{CO} 2$

GRAMS/MILE

210.9258

OMHCE

GRAMS/MILE

1.0384 (ALDEHYDES ABSENT) 
RUN NUMBER 6

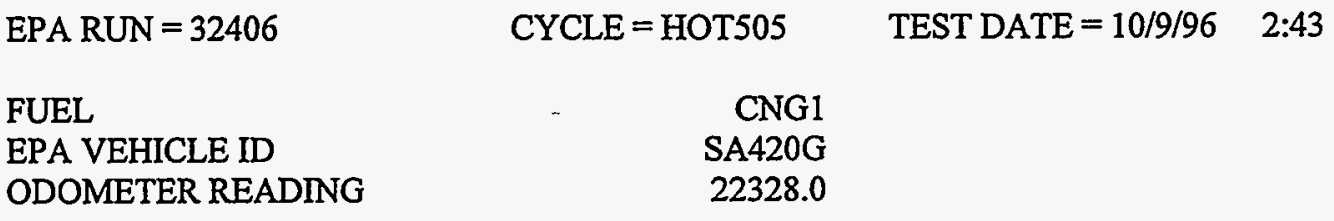

REGULATED EMISSIONS REPORT RE32

$* * * * * * * * * * * * * * * * * * * * * * * * * * * * * * * * * * * * * * * * * * * * * * * * *$

BAG 1

VMIX CUBIC FEET

DILUTION FACTOR

5314.00

28.98

FUEL ECON. MILES/GAL $\quad 31.00$

TEST DIST. MILES $\quad 3.59$

HC PPM

39.94

HC GRAMS

3.47

HC GRAMS/MILE

0.97

NOX PPM

4.00

NOX GRAMS

1.07

NOX GRAMS/MILE

0.30

\begin{tabular}{lr}
\hline CO PPM & 35.00 \\
CO GRAMS & 6.13 \\
CO GRAMS/MILE & 1.71 \\
\hline & \\
\hline & \\
CO2 $\%$ & 0.28 \\
CO2 GRAMS & 772.13 \\
\hline
\end{tabular}

** WEIGHTED VALUES **

FUEL ECON.

FUEL ECON.

$\mathrm{HC}$

NOX

$\mathrm{CO}$

$\mathrm{CO} 2$

OMHCE
MILES/GAL.

BTU/MILE

GRAMS/MILE

GRAMS/MILE

GRAMS/MILE

GRAMS/MILE

GRAMS/MILE
31.0043

4138.2444

0.9654

0.2977

1.7081

215.0776

0.9654 (ALDEHYDES ABSENT) 
RUN NUMBER 7

EPA RUN $=32407$

CYCLE $=$ FTP $\quad$ TEST DATE $=10 / 10 / 96 \quad 7: 39$

FUEL

CNG1

EPA VEHICLE ID

SA420G

ODOMETER READING

22328.0

\begin{tabular}{|c|c|c|c|c|}
\hline & BAG 124 & BAG 1 & BAG 2 & BAG 3 \\
\hline $\begin{array}{l}\text { VMIX CUBIC FEET } \\
\text { DILUTION FACTOR } \\
\text { FUEL ECON. MILES/GAL } \\
\text { TEST DIST. MILES }\end{array}$ & $\begin{array}{r}1325.00 \\
25.64 \\
20.48 \\
0.67\end{array}$ & $\begin{array}{r}5391.00 \\
25.52 \\
26.53 \\
3.59\end{array}$ & $\begin{array}{r}9274.00 \\
39.03 \\
27.69 \\
3.89\end{array}$ & $\begin{array}{r}5371.00 \\
30.46 \\
32.49 \\
3.59\end{array}$ \\
\hline $\begin{array}{l}\text { HC PPM } \\
\text { HC GRAMS } \\
\text { HC GRAMS/MILE }\end{array}$ & $\begin{array}{r}309.00 \\
6.69 \\
9.93\end{array}$ & $\begin{array}{r}124.87 \\
10.99 \\
3.06\end{array}$ & $\begin{array}{r}16.39 \\
2.48 \\
0.64\end{array}$ & $\begin{array}{r}37.62 \\
3.30 \\
0.92\end{array}$ \\
\hline $\begin{array}{l}\text { NOX PPM } \\
\text { NOX GRAMS } \\
\text { NOX GRAMS/MILE }\end{array}$ & $\begin{array}{l}2.40 \\
0.15 \\
0.22\end{array}$ & $\begin{array}{l}3.70 \\
0.91 \\
0.25\end{array}$ & $\begin{array}{l}1.40 \\
0.59 \\
0.15\end{array}$ & $\begin{array}{l}5.00 \\
1.23 \\
0.34\end{array}$ \\
\hline $\begin{array}{l}\text { CO PPM } \\
\text { CO GRAMS } \\
\text { CO GRAMS/MILE }\end{array}$ & $\begin{array}{r}78.00 \\
3.41 \\
5.06\end{array}$ & $\begin{array}{r}36.00 \\
6.40 \\
1.78\end{array}$ & $\begin{array}{r}22.00 \\
6.73 \\
1.73\end{array}$ & $\begin{array}{r}27.00 \\
4.78 \\
1.33\end{array}$ \\
\hline $\begin{array}{l}\mathrm{CO} 2 \% \\
\mathrm{CO} 2 \text { GRAMS } \\
\mathrm{CO} 2 \text { GRAMS/MILE }\end{array}$ & $\begin{array}{r}0.29 \\
200.89 \\
298.50\end{array}$ & $\begin{array}{r}0.32 \\
884.42 \\
246.36\end{array}$ & $\begin{array}{r}0.20 \\
942.49 \\
242.28\end{array}$ & $\begin{array}{r}0.27 \\
738.47 \\
205.70\end{array}$ \\
\hline
\end{tabular}

** WEIGHTED VALUES **

FUEL ECON.

FUEL ECON.

$\mathrm{HC}$

NOX

$\mathrm{CO}$

$\mathrm{CO} 2$

OMHCE
MILES/GAL.

BTU/MILE

GRAMS/MILE

GRAMS/MILE

GRAMS/MILE

GRAMS/MILE

GRAMS/MILE
28.5909

4487.5688

1.2153

0.2256

1.6315

233.1173

1.2153 (ALDEHYDES ABSENT) 
RUN NUMBER 8

EPA RUN $=32408$

$$
\text { CYCLE }=\text { HOT505 }
$$

TEST DATE $=10 / 10 / 96 \quad 9: 17$

FUEL

CNG1

EPA VEHICLE ID

SA420G

ODOMETER READING

22339.0

REGULATED EMISSIONS REPORT RE32

BAG 1

VMIX CUBIC FEET

DILUTION FACTOR

5486.00

29.16

FUEL ECON. MILES/GAL

30.37

TEST DIST. MILES

3.59

HC PPM

117.94

HC GRAMS

10.57

HC GRAMS/MILE

2.94

NOX PPM

13.70

NOX GRAMS

3.38

NOX GRAMS/MILE

0.94

CO PPM

206.00

CO GRAMS

37.26

CO GRAMS/MILE

10.38

$\mathrm{CO} 2 \%$

0.25

CO2 GRAMS

720.35

CO2 GRAMS/MILE

200.66

\section{** WEIGHTED VALUES **}

FUEL ECON.

FUEL ECON.

$\mathrm{HC}$

NOX

$\mathrm{CO}$

$\mathrm{CO} 2$

OMHCE
MILES/GAL.

BTU/MILE

GRAMS/MILE

GRAMS/MILE

GRAMS/MILE

GRAMS/MILE

GRAMS/MILE
30.3656

4225.2970

2.9432

0.9417

10.3788

200.6553

2.9432 (ALDEHYDES ABSENT) 
RUN NUMBER 9

EPA RUN $=32432$

CYCLE $=$ FTP $\quad$ TEST DATE $=11 / 25 / 96 \quad 8: 45$

FUEL CNG1

EPA VEHICLE ID SA420G

ODOMETER READING 22366.6

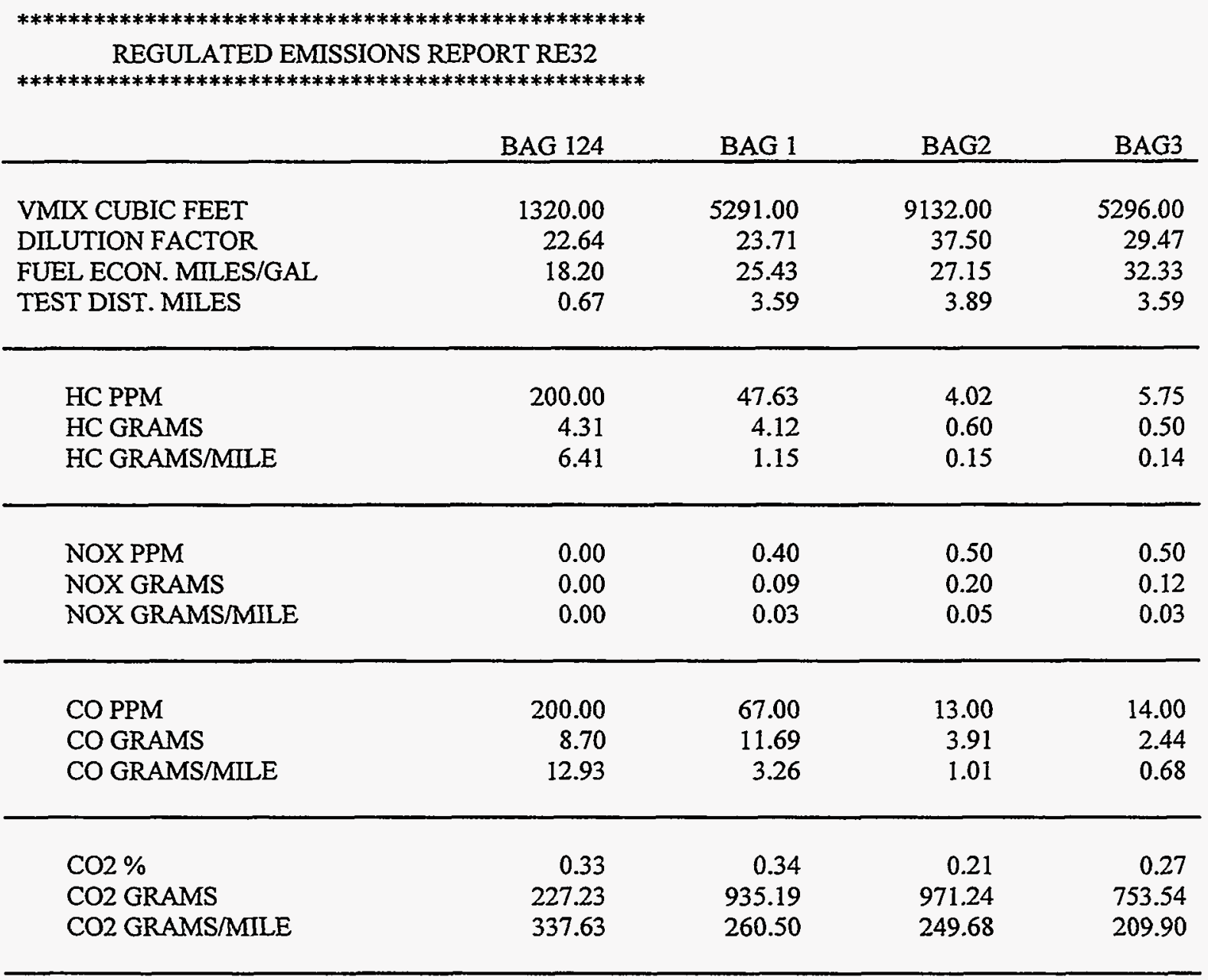

** WEIGHTED VALUES **

FUEL ECON.

FUEL ECON.

$\mathrm{HC}$

NOX

$\mathrm{CO}$

$\mathrm{CO} 2$

OMHCE
MILES/GAL.

BTU/MILE

GRAMS/MILE

GRAMS/MILE

GRAMS/MLE

GRAMS/MILE

GRAMS/MILE
27.9875

4584.3141

0.3546

0.0406

1.3814

241.0279

0.3546 (ALDEHYDES ABSENT) 
RUN NUMBER 10

EPA RUN $=32433$

CYCLE $=$ HOT505 TEST DATE $=11 / 25 / 96 \quad 10: 50$

FUEL

CNG1

EPA VEHICLE ID

SA420G

ODOMETER READING

22377.5

REGULATED EMISSIONS REPORT RE32

BAG 1

VMIX CUBIC FEET

5235.00

DILUTION FACTOR

29.55

FUEL ECON. MILES/GAL

32.82

TEST DIST. MILES

3.59

HC PPM

3.66

HC GRAMS

0.31

HC GRAMS/MILE

0.09

NOX PPM

1.50

NOX GRAMS

0.34

NOX GRAMS/MILE

0.10

\begin{tabular}{lr}
\hline CO PPM & 7.00 \\
CO GRAMS & 1.21 \\
CO GRAMS/MILE & 0.34 \\
\hline & \\
CO2\% & 0.27 \\
CO2 GRAMS & 744.85 \\
& 207.48 \\
\hline
\end{tabular}

** WEIGHTED VALUES **

FUEL ECON.

FUEL ECON.

$\mathrm{HC}$

NOX

$\mathrm{CO}$

$\mathrm{CO} 2$

OMHCE
MILES/GAL.

BTU/MILE

GRAMS/MILE

GRAMS/MILE

GRAMS/MILE

GRAMS/MILE

GRAMS/MILE
32.8156

3909.8286

0.0872

0.0952

0.3365

207.4795

0.0872 (ALDEHYDES ABSENT) 
RUN NUMBER 11

EPA RUN $=32434$

CYCLE $=$ HOT505

TEST DATE $=11 / 25 / 96 \quad 1: 27$

FUEL

CNG1

EPA VEHICLE ID

SA420G

ODOMETER READING

22385.8

REGULATED EMISSIONS REPORT RE32

$* * * * * * * * * * * * * * * * * * * * * * * * * * * * * * * * * * * * * * * * * * * * * * * * *$

BAG 1

VMIX CUBIC FEET

DILUTION FACTOR

5257.00

28.36

FUEL ECON. MILES/GAL $\quad 30.85$

TEST DIST. MILES

3.59

HC PPM

14.86

HC GRAMS

1.28

HC GRAMS/MILE

0.36

NOX PPM

1.20

NOX GRAMS

0.28

NOX GRAMS/MILE

0.08

CO PPM

71.00

CO GRAMS

12.31

CO GRAMS/MILE

3.43

$\mathrm{CO} 2 \%$

CO2 GRAMS

772.39

CO2 GRAMS/MILE

215.15

\section{** WEIGHTED VALUES **}

FUEL ECON.

FUEL ECON.

$\mathrm{HC}$

NOX

CO

$\mathrm{CO} 2$

OMHCE
MILES/GAL.

BTU/MILE

GRAMS/MILE

GRAMS/MILE

GRAMS/MILE

GRAMS/MILE

GRAMS/MILE
30.8504

4158.8939

0.3554

0.0785

3.4278

215.1508

0.3554 (ALDEHYDES ABSENT) 
RUN NUMBER 12

EPA RUN $=32435$

CYCLE $=$ HOT505 TEST DATE $=11 / 25 / 96 \quad 2: 25$

FUEL

CNG1

EPA VEHICLE ID

SA420G

ODOMETER READING

22389.5

REGULATED EMISSIONS REPORT RE32

BAG 1

VMIX CUBIC FEET

5274.00

DILUTION FACTOR .

31.91

FUEL ECON. MILES/GAL

34.48

TEST DIST. MILES

3.59

HC PPM

0.84

HC GRAMS

0.07

HC GRAMS/MILE

0.02

NOX PPM

1.60

NOX GRAMS

0.38

NOX GRAMS/MILE

0.11

\begin{tabular}{lr}
\hline CO PPM & 1.00 \\
CO GRAMS & 0.17 \\
CO GRAMS/MILE & 0.05 \\
\hline & \\
\hline CO2\% & 0.26 \\
CO2 GRAMS & 711.05 \\
& 198.06 \\
\hline
\end{tabular}

** WEIGHTED VALUES **

FUEL ECON.

FUEL ECON.

$\mathrm{HC}$

NOX

$\mathrm{CO}$

$\mathrm{CO} 2$

OMHCE
MILES/GAL.

BTU/MILE

GRAMS/MILE

GRAMS/MILE

GRAMS/MILE

GRAMS/MILE

GRAMS/MILE
34.4802

3721.0825

0.0203

0.1050

0.0484

198.0630

0.0203 (ALDEHYDES ABSENT) 
RUN NUMBER 13

$\begin{array}{lcc}\text { EPA RUN }=32436 & \text { CYCLE }=\text { FTP } & \text { TEST DATE }=11 / 26 / 96 \\ \text { FUEL } & \text { CNG1 } \\ \text { EPA VEHICLE ID } & \text { SA420G } \\ \text { ODOMETER READING } & 22396.0\end{array}$

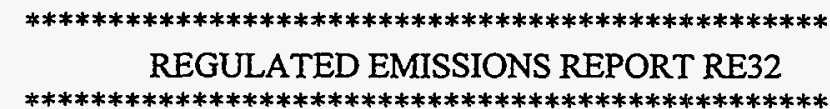

BAG 124

BAG 1

BAG2

BAG3

VMIX CUBIC FEET

DILUTION FACTOR

1300.00

24.01

19.28

5264.00

24.72

26.13

9084.00

39.50

28.26

5257.00

0.67

3.59

3.89

30.38

33.04

TEST DIST. MILES

180.00
3.82
5.68

44.19

3.80

1.06

1.60

0.24

5.93

HC GRAMS

5.68

0.06

0.14

\begin{tabular}{lrrrr}
\hline NOX PPM & 0.90 & 0.40 & 0.40 & 0.60 \\
NOX GRAMS & 0.06 & 0.11 & 0.18 & 0.16 \\
NOX GRAMS/MILE & 0.09 & 0.03 & 0.05 & 0.04 \\
& & & & \\
\hline & & & & \\
CO PPM & 69.00 & 27.00 & 7.00 & 7.00 \\
CO GRAMS & 2.96 & 4.69 & 2.10 & 1.21 \\
CO GRAMS/MILE & 4.39 & 1.31 & 0.54 & 0.34 \\
& & & & \\
CO2 \% & 0.33 & 0.34 & 0.20 & 0.27 \\
CO2 GRAMS & 223.44 & 921.00 & 936.88 & 739.15 \\
CO2 GRAMS/MILE & 332.01 & 256.55 & 240.84 & 205.89 \\
& & & & \\
\hline
\end{tabular}

** WEIGHTED VALUES **

FUEL ECON.

FUEL ECON.

$\mathrm{HC}$

NOX

$\mathrm{CO}$

$\mathrm{CO} 2$

OMHCE
MILES/GAL.

BTU/MILE

GRAMS/MILE

GRAMS/MILE

GRAMS/MILE

GRAMS/MILE

GRAMS/MILE
28.9170

4436.9595

0.2889

0.0426

0.6421

234.5216

0.2889 (ALDEHYDES ABSENT) 
RUN NUMBER 14
EPA RUN $=32437$
CYCLE $=$ HOT505
TEST DATE $=11 / 26 / 96 \quad 9: 14$
FUEL
CNG1
EPA VEHICLE ID
SA420G
ODOMETER READING
22411.9

******************************************************

REGULATED EMISSIONS REPORT RE32

BAG 1

VMIX CUBIC FEET

5257.00

DILUTION FACTOR

31.35

34.27

FUEL ECON. MILES/GAL

3.59

TEST DIST. MILES

3.63

HC PPM

0.31

HC GRAMS

0.09

HC GRAMS/MILE

1.30

NOX PPM

0.33

NOX GRAMS

0.09

NOX GRAMS/MILE

2.00

CO PPM

0.35

CO GRAMS

0.10

CO GRAMS/MILE

$\mathrm{CO} 2 \%$

714.52

CO2 GRAMS

199.03

CO2 GRAMS/MILE

** WEIGHTED VALUES **

FUEL ECON.

FUEL ECON.

$\mathrm{HC}$

NOX

$\mathrm{CO}$

$\mathrm{CO} 2$

OMHCE
MILES/GAL.

BTU/MILE

GRAMS/MILE

GRAMS/MILE

GRAMS/MILE

GRAMS/MILE

GRAMS/MILE
34.2680

3744.1159

0.0869

0.0908

0.0966

199.0311

0.0869 (ALDEHYDES ABSENT) 


\section{Appendix C}

\section{Calculation of Reactivity-Adjusted NMOG Emissions}

In order to account for the reactivity of the exhaust organics emitted by different fuels, the California Air Resources Board procedure as amended on June 24, 1996 for 1993-2000 modelyear LEV's and ULEV's allows the exhaust NMOG resulting from certain fuels to be multiplied by a reactivity adjustment factor (RAF) to produce the reactivity adjusted NMOG (RANMOG). For natural gas the RANMOG is found by multiplying the measured NMOG by the specified reactivity adjustment factor of 0.43 and adding to it the mass of methane emitted times its specified reactivity adjustment factor of 0.0047 . The NMOG is the sum of the NMHC and the carbonyls (primarily formaldehyde) produced. For test 13 the calculation is:

RANMOG $=0.43(0.014+0.004)+0.0047(.262)=0.0090 \mathrm{~g} / \mathrm{mi}$ 


\section{Appendix D}

Acceleration Test Results 


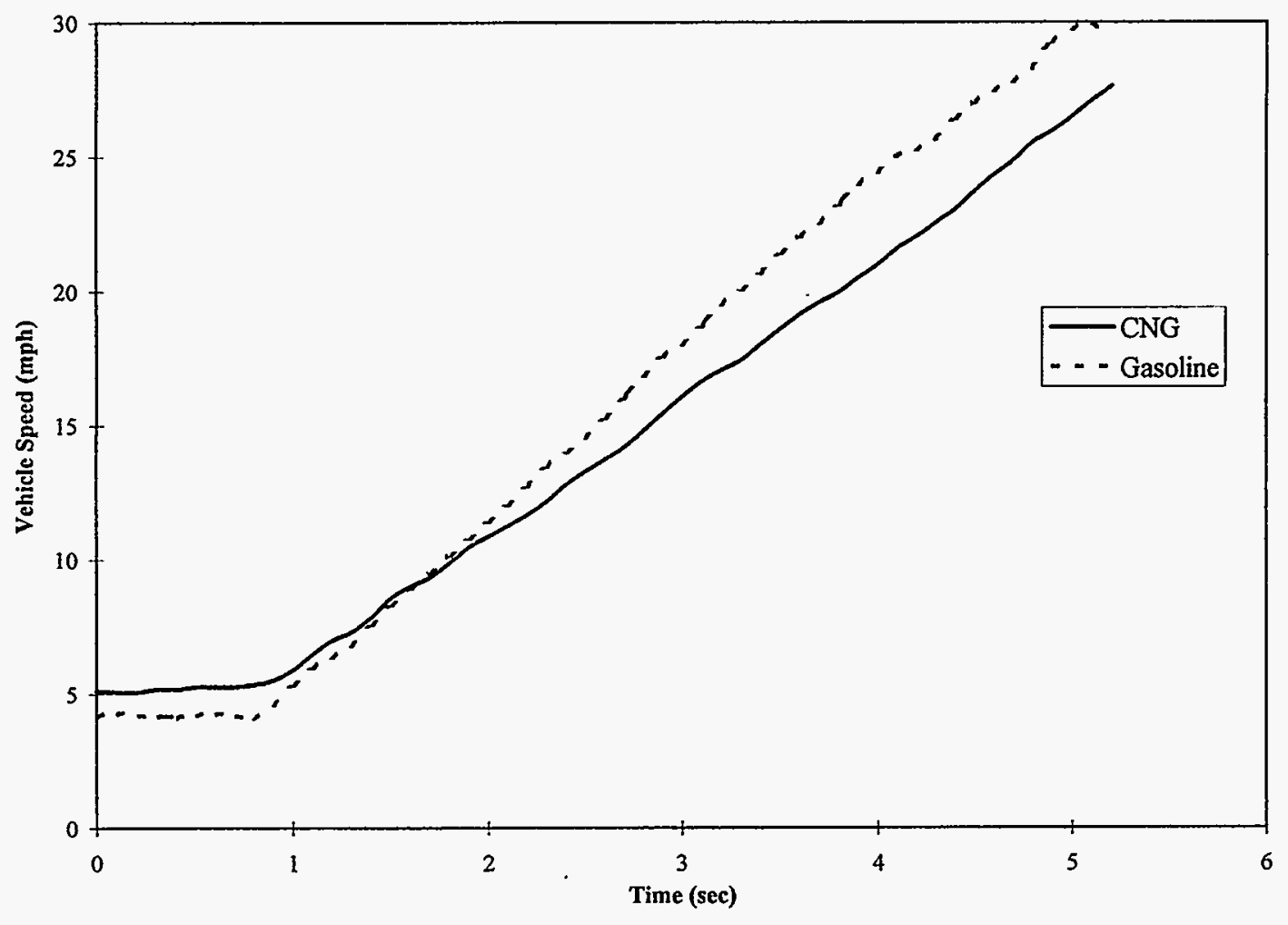

Figure D1. Vehicle speed as a function of time (1st gear)

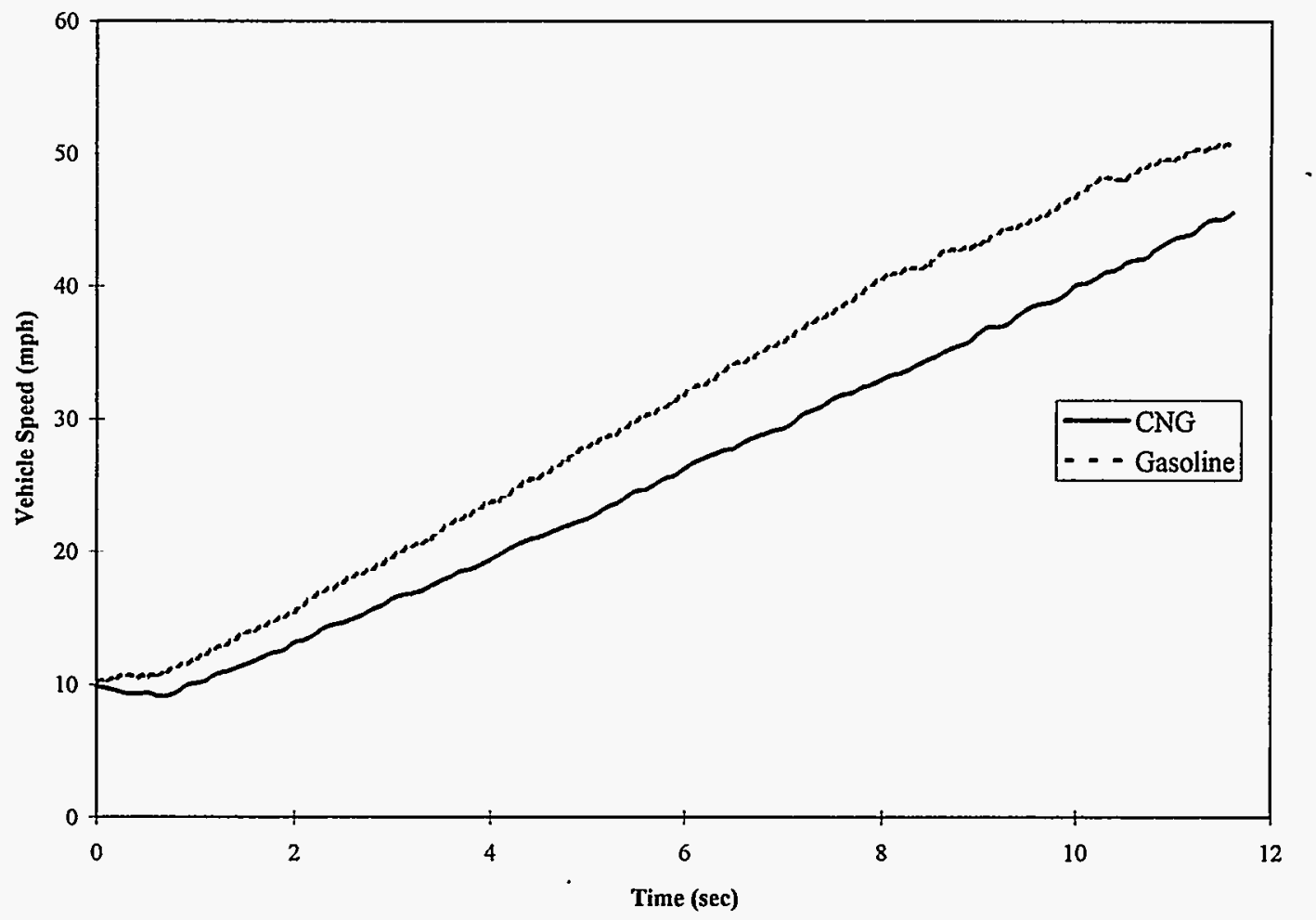

Figure D2. Vehicle speed as a function of time (2nd gear) 


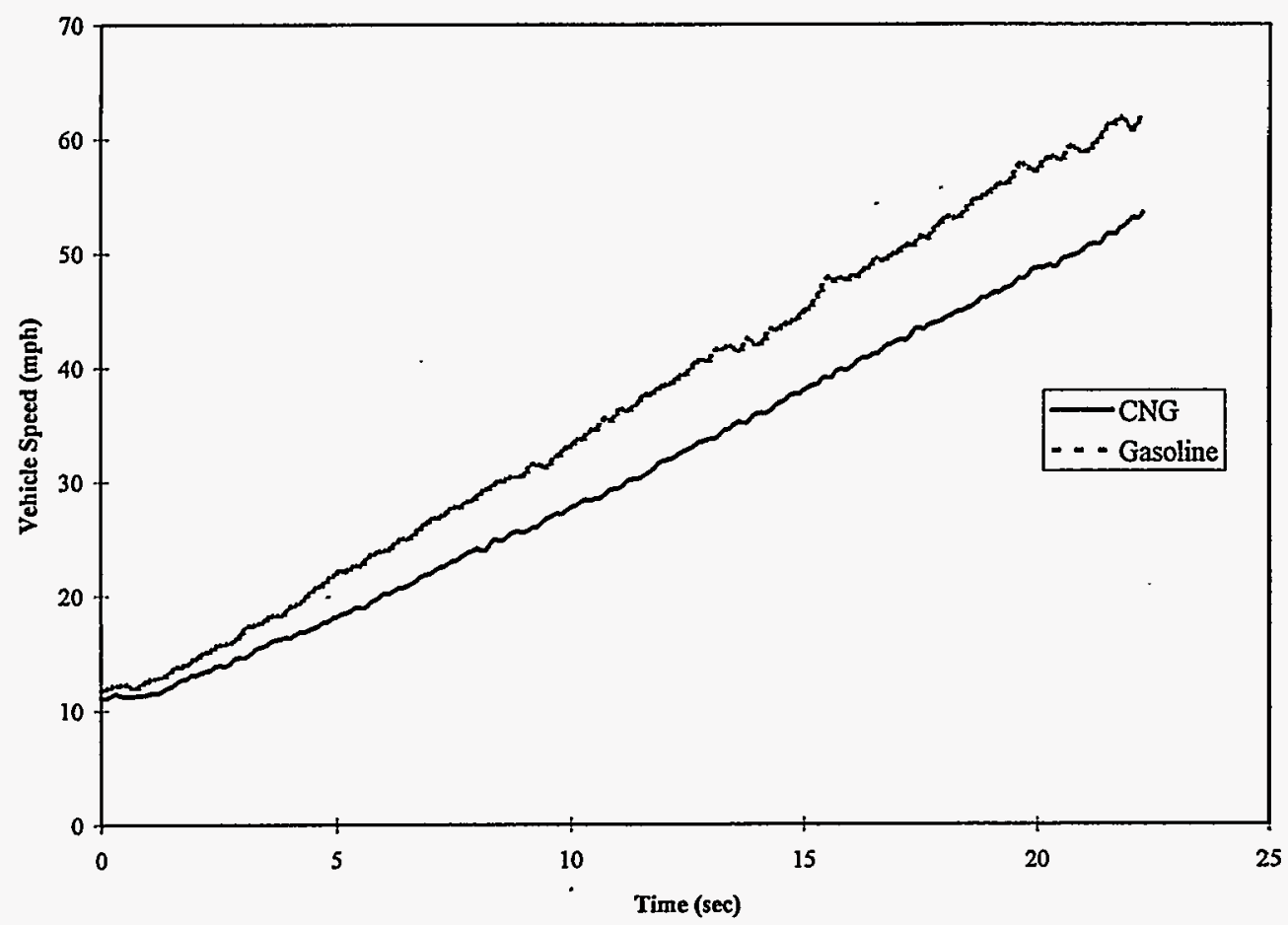

Figure D3. Vehicle speed as a function of time (3rd gear)

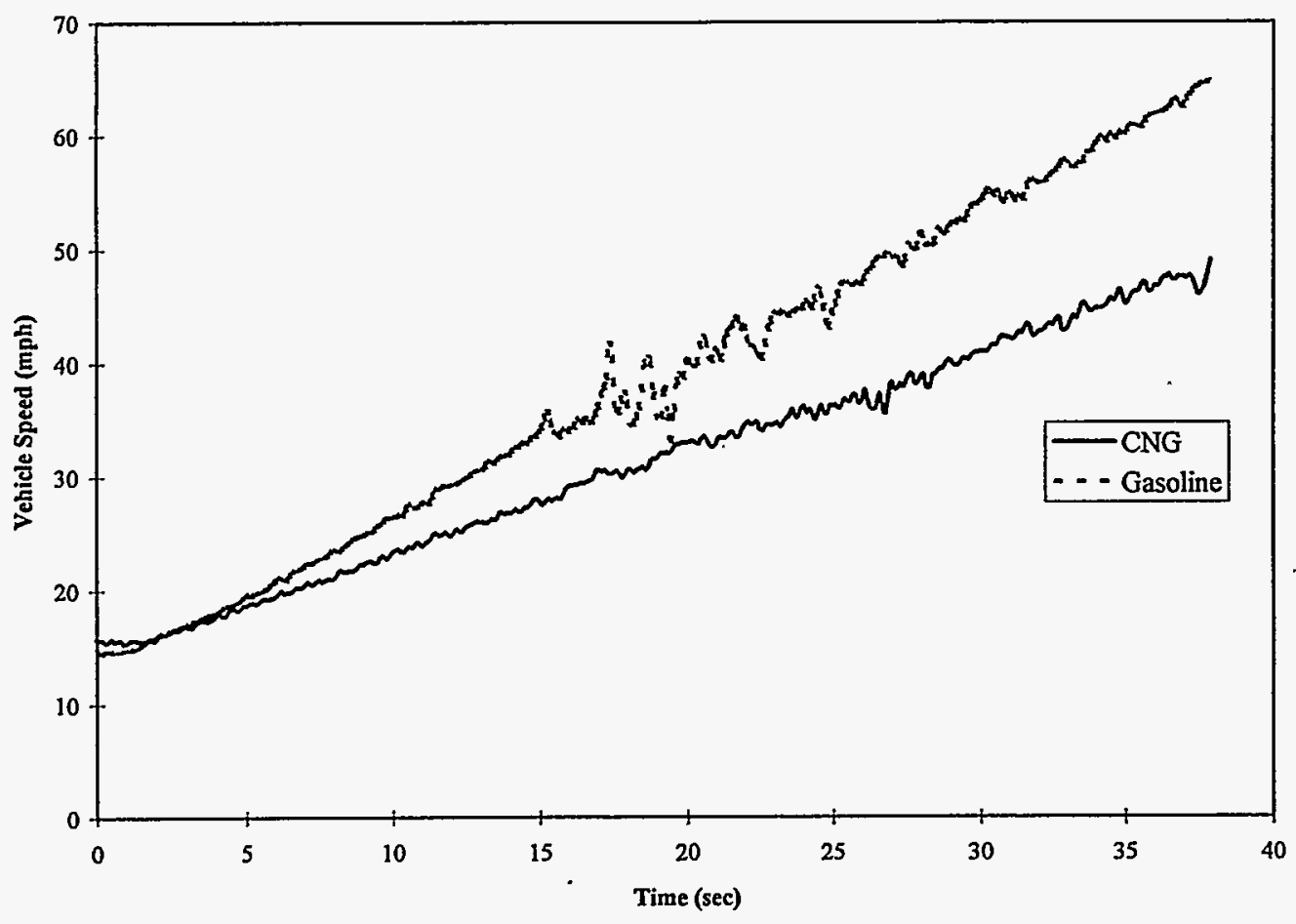

Figure D4. Vehicle speed as a function of time (4th gear) 


\section{REPORT DOCUMENTATION PAGE}

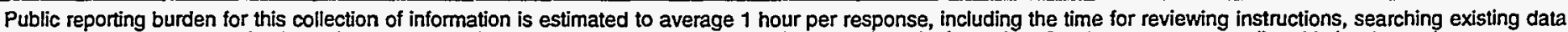

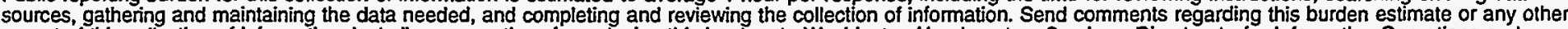

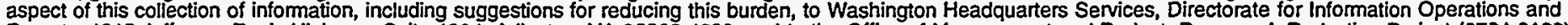

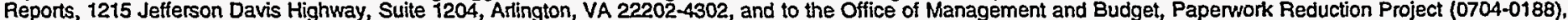
Washington, DC 20503.
1. AGENCY USE ONLY (Leave blank)
2. REPORT DATE
July 1997
3. REPORT TYPE AND DATES COVERED
Subcontract report

\section{TITLE AND SUBTITLE}

Emissions and Performance Evaluation of a Dedicated Compressed Natural Gas Satum

\section{AUTHOR(S)}

J. W. Hodgson and J. D. Taylor

\section{PERFORMING ORGANIZATION NAME(S) AND ADDRESS(ES)}

The University of Tennessee

Mechanical and Aerospace Engineering and Engineering Science Department

414 Dougherty Hall

Knoxville, Tennessee $37996-2210$

\section{SPONSORING/MONITORING AGENCY NAME(S) AND ADDRESS(ES)}

National Renewable Energy Laboratory

1617 Cole Boulevard

Golden, CO 80401-3393

\section{SUPPLEMENTARY NOTES}

\section{2a. DISTRIBUTION/AVAILABILITY STATEMENT}

National Technical Information Service

U.S. Department of Commerce

5285 Port Royal Road

Springfield, VA 22161

\section{FUNDING NUMBERS}

(C) XCF-5-14050-03

(TA) FU621010

8. PERFORMING ORGANIZATION REPORT NUMBER

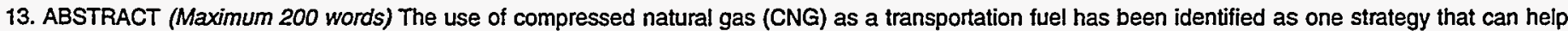

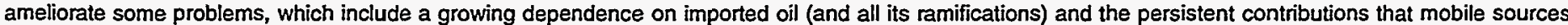

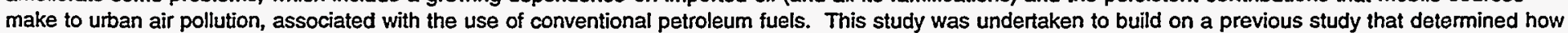

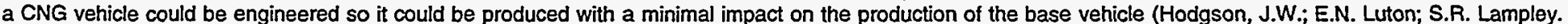

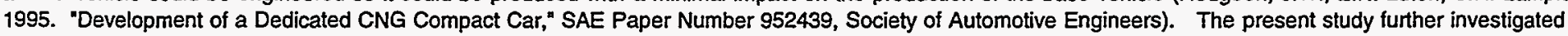
the emissions reduction potential of the Satum CNG vehicle.

\section{SUBJECT TERMS}

Alternative fuels, transportation fuels, air quality, emissions, compressed natural gas, Satum vehicles OF REPORT
17. SECURITY CLASSIFICATION
18. SECURITY CLASSIFICATION OF THIS PAGE
19. SECURITY CLASSIFICATION OF ABSTRACT
15. NUMBER OF PAGES

16. PRICE CODE

20. LIMITATION OF ABSTRACT

Standard Form 298 (Rev, 2-89) Prescribed by ANSI Std. Z39-18 